Historic, Archive Document

Do not assume content reflects current scientific knowledge, policies, or practices. 


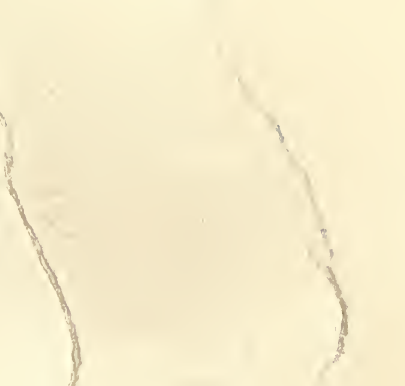




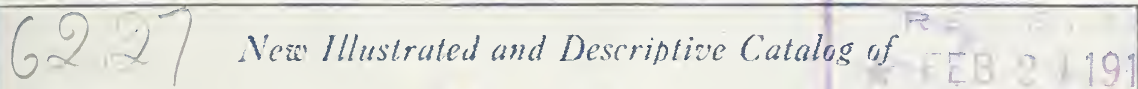
Fruit and Ornamental

Trees, Small Fruits, Shrubs, Vines and Roses

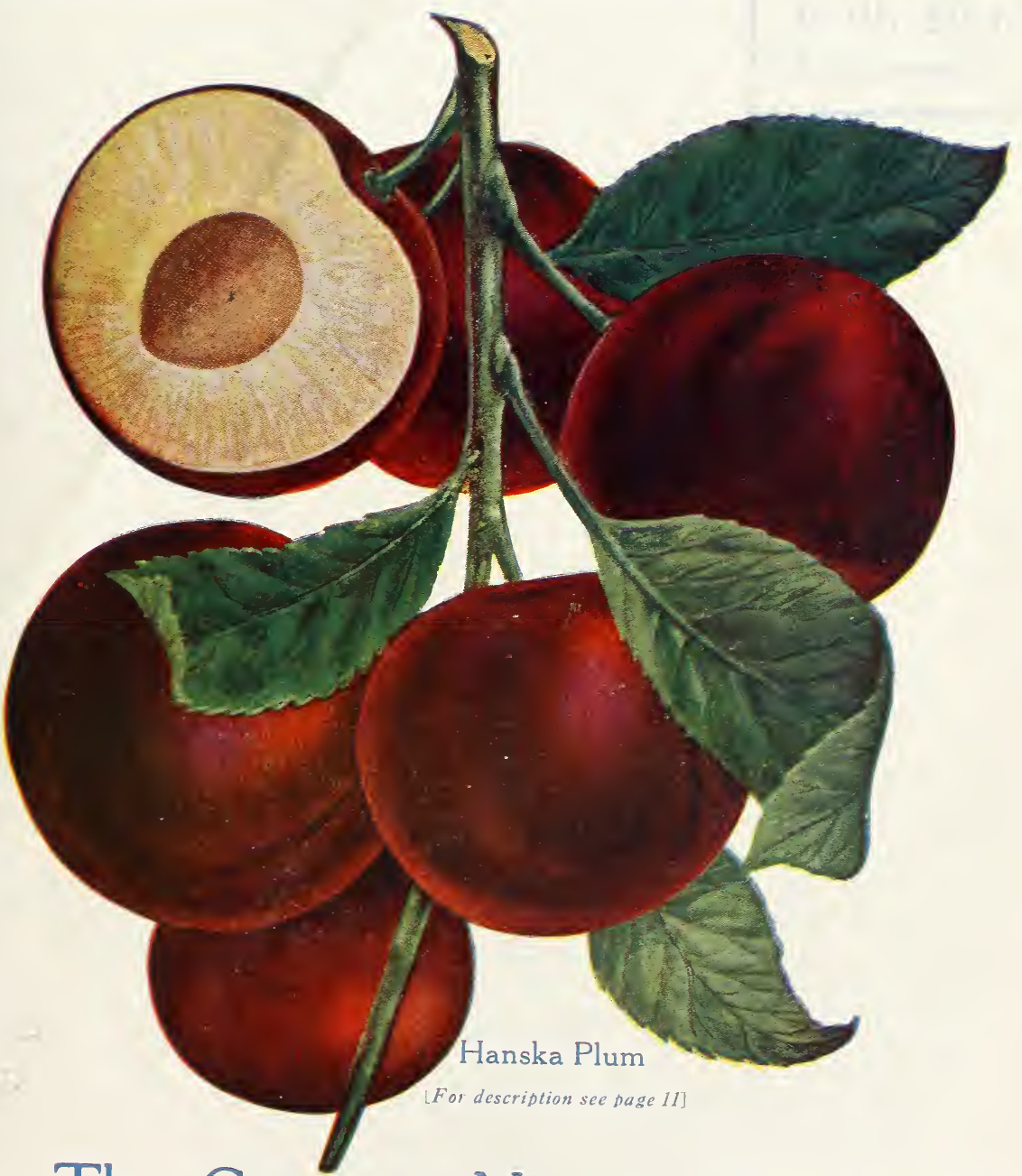

The Gateway Nursery Company WHOLESALE AND RETAIL

We are the Largest Growers of Nursery Stock in the Northwest Enabling us to Supply Your Every Need LE MARS, IOWA 

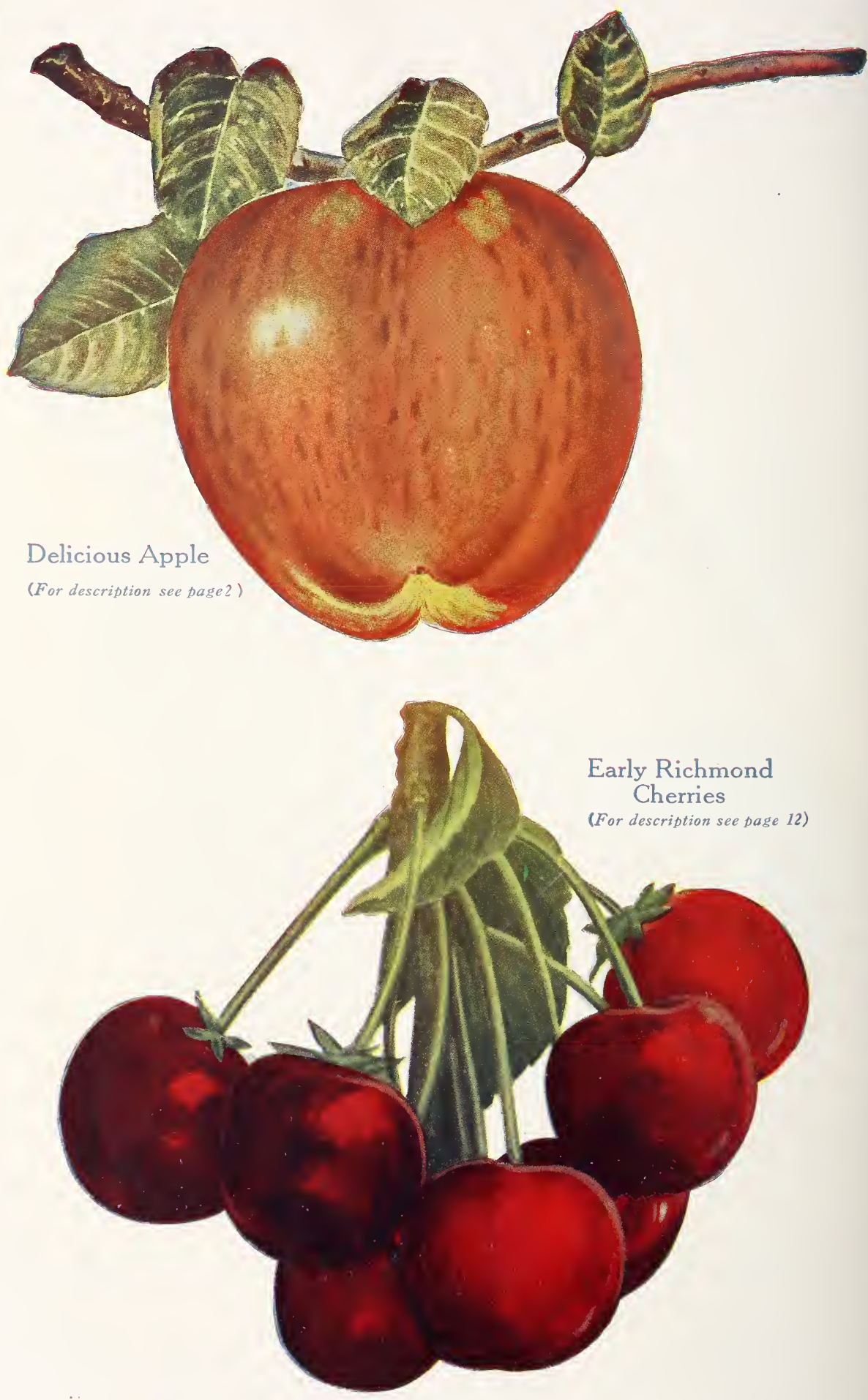


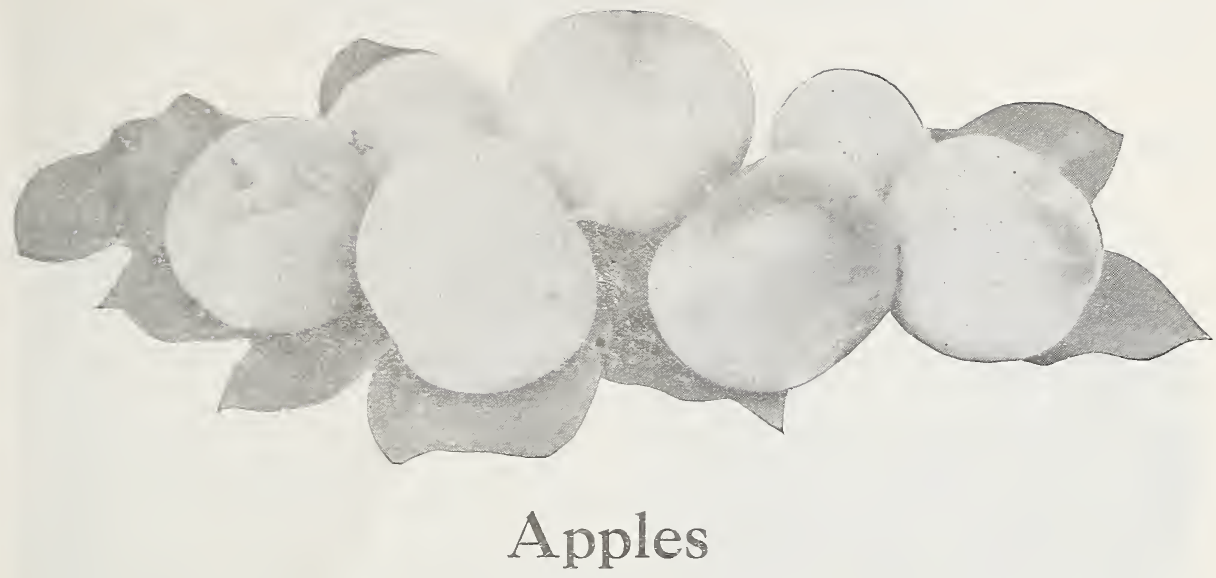

Taking into consideration its hardiness, productiveness and general commercial value, the apple stands at the head of the list of fruits. In selecting the most important varieties for cultivation, it has been our constant aim to secure only those of standard excellence, and in no instance to recommend a novelty without ascertaining its history from a reliable source.

\section{Summer Apples}

BENONI-Medium; roundish; pale yellow, shaded with crimson, juicy, tender sub-acid. August.

DUCHESS OF OLDENBURG - A large, beautiful apple, roundish. Streaked red and yellow. Tender, juicy and pleasant. Tree a vigorous, fine grower and abundant bearer. Very hardy. September.

EARLY HARVEST-Tree healthy, vigorous and a good bearer. Fruit medium size, nearly round, somewhat flattened; surface smooth, clear, waxy yellow, rarely blushed; flesh tender, juicy, acid to sub-acid, flavor good. July.

GOLDEN SWEET-Large, pale yellow, very sweet and good; good bearer; free. August.

LIVELAND (Liveland Raspberry)-Color orange yellow, striped, splashed and shaded with red, showing gray dots through the color, flesh light yellow, often stained with red; fine, tender, juicy; core medium open; flavor sub-acid, good.

RED ASTRACHAN-Tree vigorons, 11pright, hardy and productive. Fruit medium to large; suriace smooth, marbled and striped on greenish yellow; flavor acid.

RED JUNE-Medium, red; flesh white, tender; juicy, good flavor. Abundant bearer. Last of June.

\section{Autumn Varieties}

CHENANGO (Strawberry)-Rather large, oblong, conical, angular; whitish-yellow striped and splashed with light crimson; flesh white, very tender, with mild, pleasant sub-acid flavor. A market and eating variety. Tree vigorous and productive.
YELLOW TRANSPARENT-A Russian apple. The tree is a hardy, upright grower; regular and early bearer, medium size. Color a rich, transparent yellow with a faint blush on sunny side; flesh melting, juicy, sub-acid.

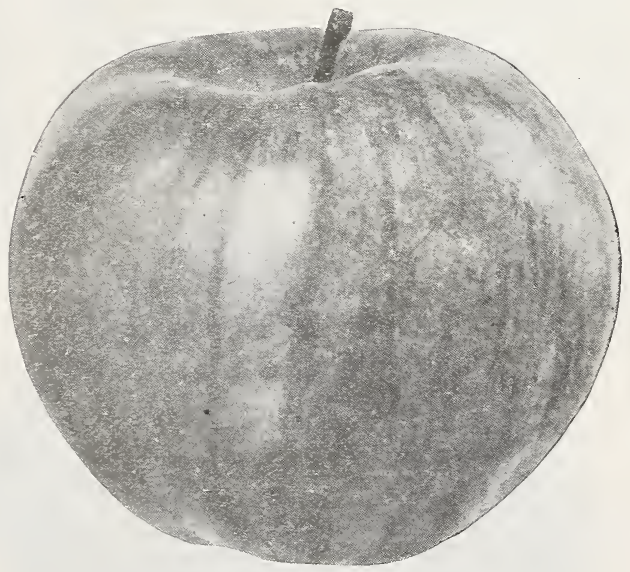

Duchess of Oldenburg
FAMEUSE (Snow Apnle)-Medium size, roundish; crimson, sometimes striped in northern localities. Flesh snowy white; very tender, nne, juicy, mild, sub-acid; one of the finest dessert fruits. Hardy and prolific. Very popular. Oc. tober and December. 


\section{Autumn Varieties-Continued}

GRAVENSTEIN-Large, rather flat; yellow, with red stripes; beautiful and showy; flesh firm,

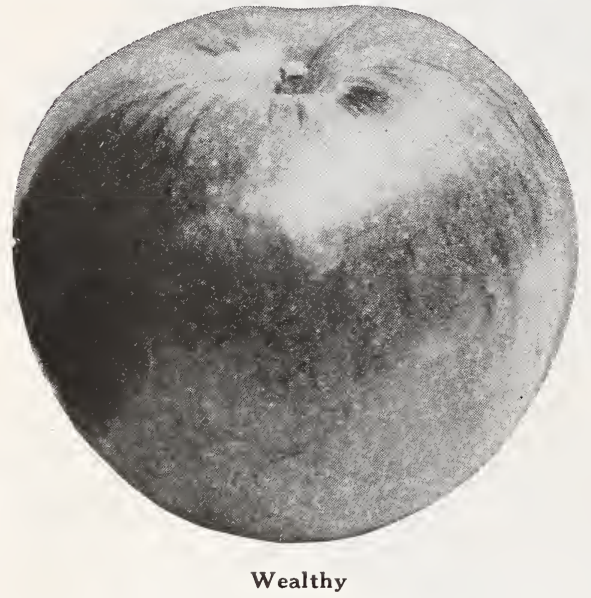

tender and crisp, highly flavored; cooking and market. Generally recommended as a good fall variety.

MAIDEN BLUSH-Large, smooth, regular, evenly shaded red cheek or blush on a pale yellow ground; flesh white, tender, sprightly, with a pleasant sub-acid flavor; bears large crops; free. August to October.

RAMBO--Medium; yellow, striped with red. Fruit mild, tender, good. September to November.

UTTER (Red)-Rather large; red striped. Very hardy on prairie; productive and of excellent quality. Immensely popular where known. September to December.

WOLF RIVER-Extra large and handsome; deep red; excellent for cooking. Extremely hardy in the north. Probably the largest red apple adapted to this region. September to November.

WEALTHY-Origin, Minnesota, Large, round; red; very handsome; fine quality; good grower. Perfectly hardy and most reliable. Very popular throughout the north. Long keeper in cold storage. October to January.

\section{Winter Varieties}

ARKANSAS BLACK-Vigorous, upright grower. Fruit medium to large; fine flavor, beautiful dark color, almost black; flesh yellowish slightly sub-acid, crisp. One of the best for cooking. January to March.

BALDWIN-Large; deep, bright red. Flesh juicy, crisp and of good flavor. Tree vigorous in the East and South, though not sufficiently hardy North. November and December.

BEN DAVIS-Tree thrifty, upright grower of almost perfect shape. Fruit large, round, sometimes variable in form; surface smooth, often polished yellow, covered and splashed bright red; flesh white, tender, juicy, flavor sub-acid, not rich quality; only good for market and cooking. November to Spring.

DELICIOUS-Flourishes well in every state of the Union. Bears annually; great yielder; hangs well on trees. Trees very thrifty, long lived and extremely hardy. Fruit very large, nearly covered with brilliant, dark red; flesh fine grained, crisp, juicy, melting and delicious; splendid keeper and shipper; should be in every orchard.

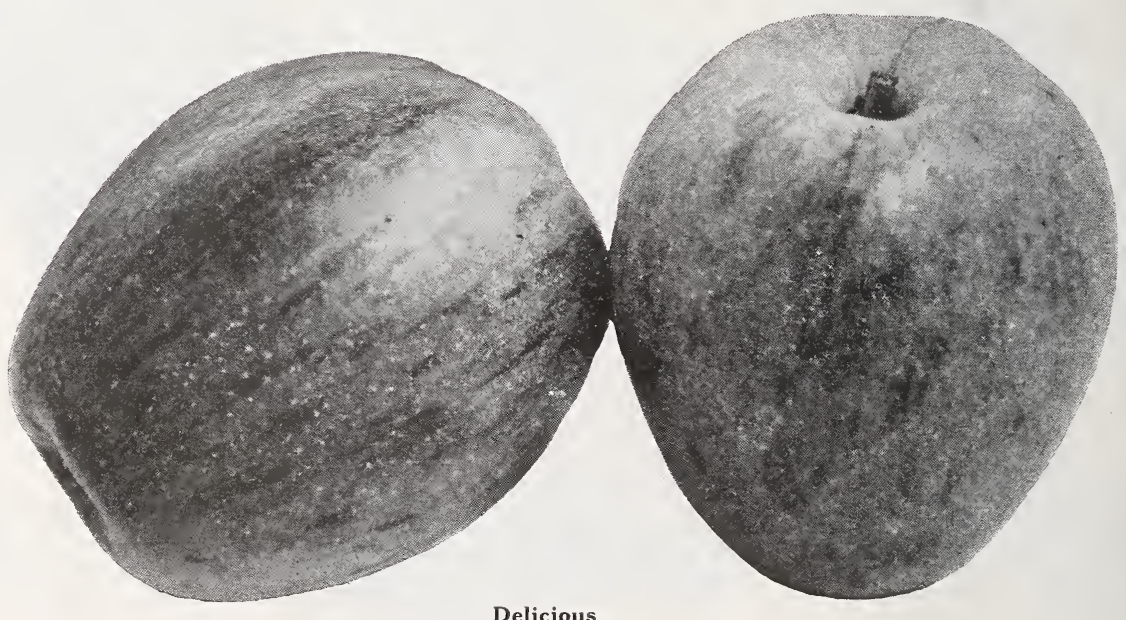

Delicious 


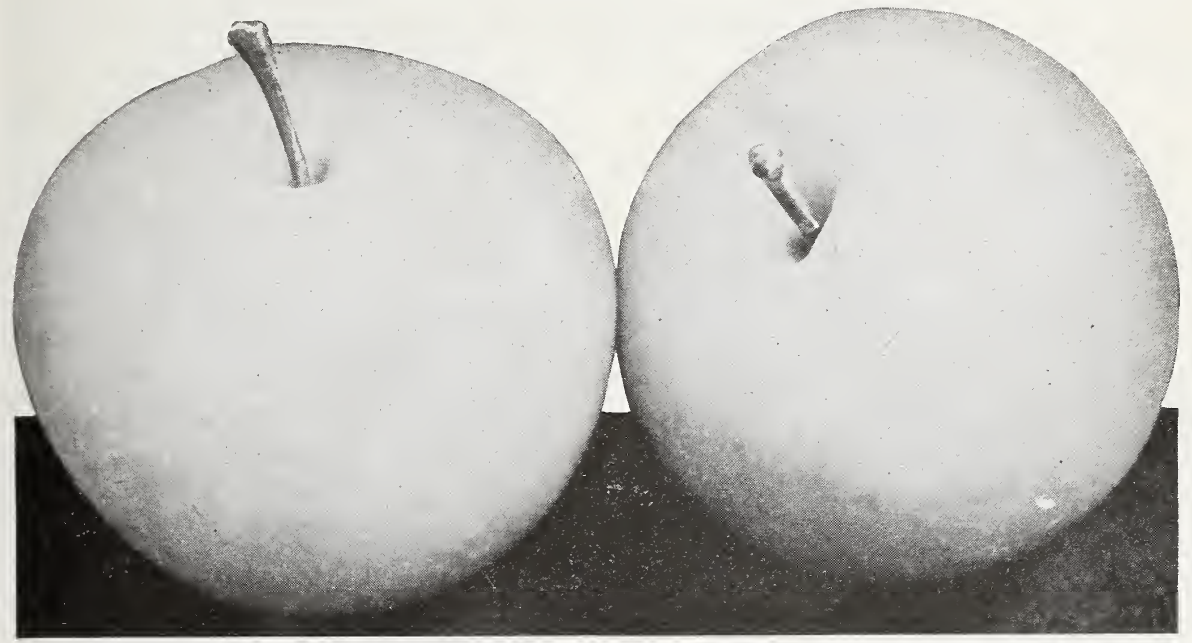

\section{Grimes Golden}

GANO-Fruit is bright red on yellow ground, with no stripes; large, oblong, surface smooth, polished; dots minute; basin shallow, sometimes deep; eye large, cavity deep; brown in color; stem medium to long; core medium. Tree healthy, vigorous and prolific bearer. January to April.

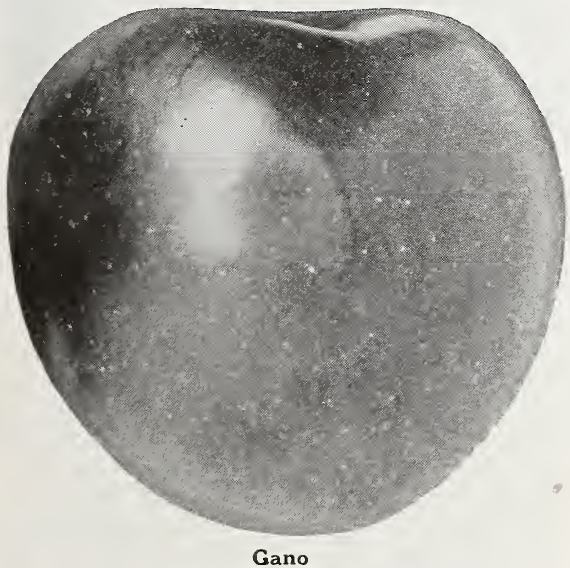

GRIMES GOLDEN-This is one of the most popular apples in cultivation. Tree strong, thrifty grower. Fruit medium or above, cylindrical; regular surface, yellow veined, rus. seted; flesh yellow, firm, very fine grained, juicy; flavor sub-acid; quality rich. For dessert, cooking and market. November and December.

HIBERNAL - (Corsimui) - Large; handsome striped with red; sub-acid; recommended for cooking; keeps till mid-winter. Hardy.

JONATHAN-Tree of rather slender growth and spreading habit; fruit medium or above in size, round or oblong; surface very smooth, waxy yellow, often wholly covered with bril- liant red; flesh whitish yellow, tender, very juicy; for dessert and cooking; quality best. October and November.

LONGFIELD-One of the imported Russian varieties; a free, upright grower, early and abundant bearer, fruit medium to large, waxen yellowish blushed with red stripes; rich, sprightly, sub-acid. Fine flavored and of delightful quality. Bears very early when topworked on some suitable stock.

MALINDA-This fine late keeper has flourished and borne fruit in Minnesota and northern Iowa for more than twenty years, and has proven hardier than any other long keeper. Fruit medium, conical, yellow, fine-grained and nearly sweet.

MAMMOTH BLACK TWIG-Fxtra large size, round, skin smooth, yellowish, covered with deep red, the general effect being dark red; flesh tender, tinged with yellow, crisp, subacid, aromatic, of excellent quality in every way. Tree vigorous, healthy and bears when quite young; very prolific.

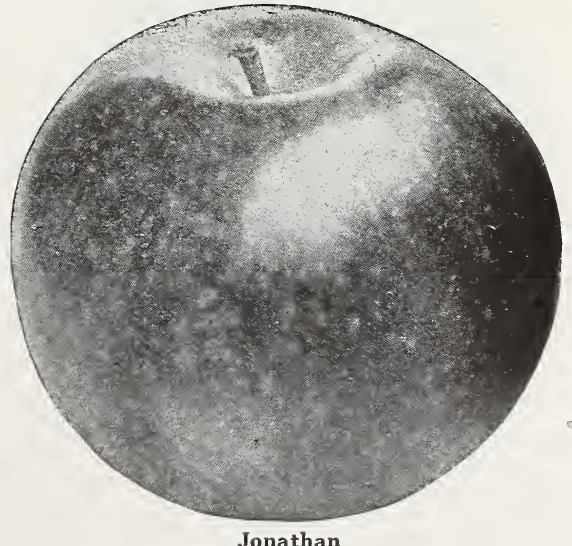

Jonathan 


\section{Winter Varieties-Continued}

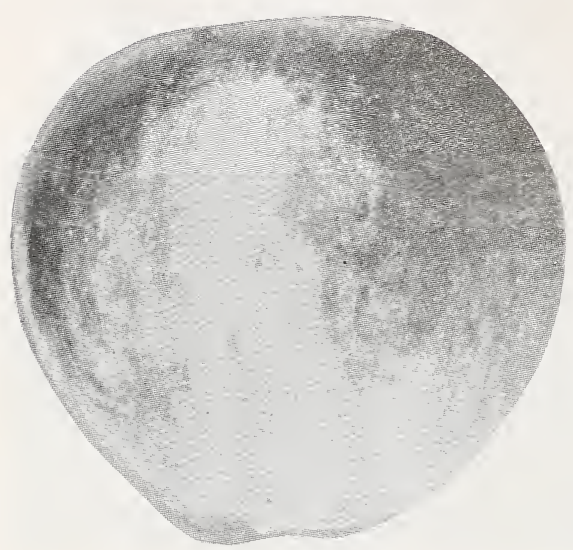

Northern Spy

NORTHERN SPY-Large; ro und is h; slightly conical; striped with sunny side purplish-red; flesh white and tender, with mild, rich, spicy flavor. An old favorite and one of the best all-around apples grown. Tree is a strong, upright grower, head very compact and should be opened up by pruning to admit air and light. December-June.

McINTOSH - (McIntosh Red) - Medium large; polished; smooth; yellow, nearly covered with brilliant crimson; beautiful; flesh snow white, crisp, very tender, aromatic; sub-acid; very good quality. Resembles Fameuse type, but is larger and more hardy. Tree vigorous, with spreading head; a good annual bcarer; popular in northwest. November to February.

OKABENA-Medium size; striped with red; similar to Duchess; flesh good, mild, subacid; dessert and cooking. Tree origi. nated in Minnesota and is a hardy, vigorous grower. Medium late.

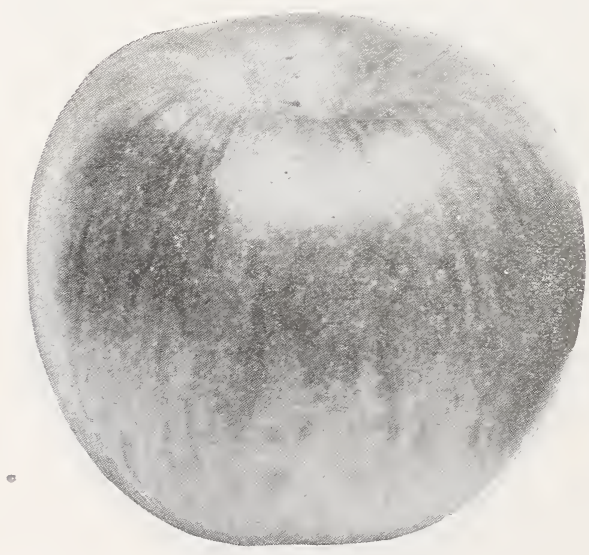

Pewaukee
NORTHWESTERN GREENING-Fruit medium to large, averaging from seven to eight, ounces each and very uniform in size. Color greenish yellow, flesh juicy, firm and fine grained. Very fine quality and flavor. Tree is very hardy and a thrifty grower, an early and continuous bearer. One of the longest keepers known. January to spring.

PATTEN'S GREENING-Duchess seedling; vcry large; flavor pleasant, sprightly, sub-acid. Superior for cooking. December to February.

PEWAUKEE-A seedling of Oldenbirg. Medium to large, roundish, oblate; skin brightish yellow, striped and splashed with dark red, and overspread with whitish dots; flesh white, tender, sub-acid, quality fair; tree vigorous, extremely hardy, especially for cold and severe climates, one of the iron-clads. January to May.

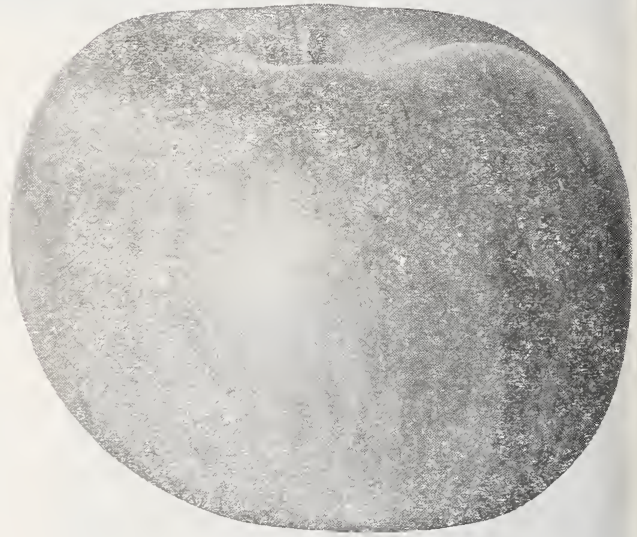

MeInะosh.

RAWL JANET-Tree good grower, not so large as some; fruit medium; somewhat conical, regular; surface smooth, mixed and striped on ycllow and green; flesh yellowish, crisp, fine grained, juicy; flavor sub-acid; quality good to very good. For dessert, kitchen, market and cider. November to spring.

RHODE ISLAND GREENING Large, greenisli yellow, tender, juicy and rich, with rather an acid flavor; growing strong and spreading, and an abundant bearer, but drops prematurely in the West, and should be gathered early if planted at all. November and December.

ROMAN STEM-Tree moderate grower and productive; fruit medium, globular; surface smooth, yellow, sometimes blushed; flesh yellowish white, fine grained and juicy; flavor mild sub-acid; quality very good; for table use. Octobcr to December.

RUSSET-Medium to large, greenish or yellow russet, crisp, good sub-acid flavor, productive, very popular on account of its long keeping; vigorous. December to May. 


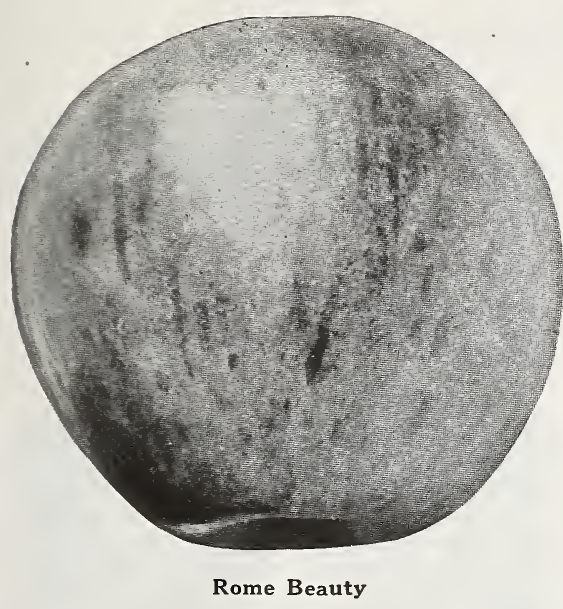

ROME BEAUTY - (Gillett's Seedling.) Large, yellow, striped with red, flesh juicy, crisp, subacid, tree moderate grower. October to Decem. ber.

SALOME-Fruit of medium and uniform size; quality very good; early; an annual bearer. Tree a strong grower and hardy.

SCOTT'S WINTER-Extra hardy, red striped. A valuable variety, hardy; thrifty grower, bears young. Fruit medium size, roundish; surface deep red and light red in blotches and streaks. Flesh yellowish white, slightly reddened near the skin; rather acid and good in quality.

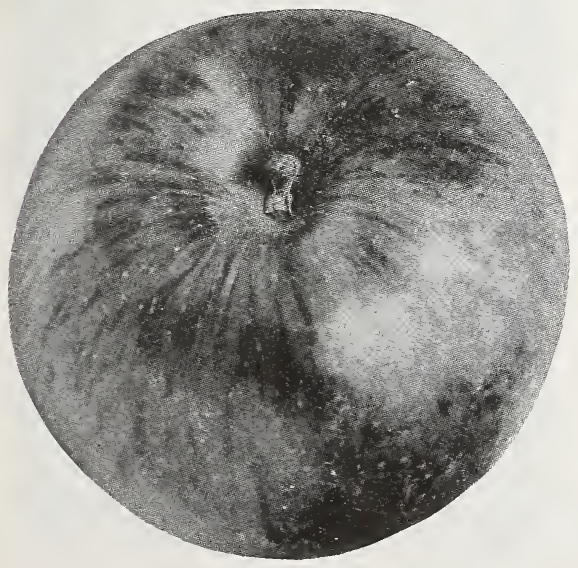

\section{Scott's Winter}

TALMAN SWEET-Medium size, pale yellow, slightly tinged with red; firm, rich and sweet: excellent for preserving; tree vigorous, very hardy and productive. November to April.

WALBRIDGE-Medium size; handsome, pale yellow, striped with red; crisp, a late keeper; tree very vigorous, extremely hardy in the North. January to May.

WILLOW TWIG Large, roundish; greenish yellow, striped with dull red; flesh firm, rather coarse; pleasant sub-tart flavor; fine for cooking.

WINESAP - (Stayman's.) Large roundish; deep red; medium quality; keeps well; tree a fair grower and good bearer. December to May.

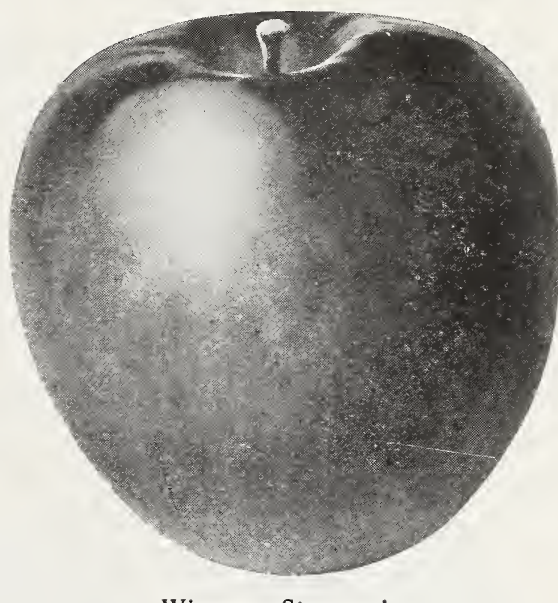

Winesap, Stayman's

WINTER BANANA-A highly prized and valuable market sort. Beautiful yellow fruit; flavor exquisite and very tempting; highest quality. Productive. Reliable growers represent it to be hardy North. Very popular for dessert.

YORK IMPERIAL-Tree moderate grower and productive, fruit large, lop-sided; surface smooth; color mixed bright red on yellow ground; flesh yellowish, tender, juicy, flavor mild sub-acid; quality very good; for market, table, kitchen. November till spring.

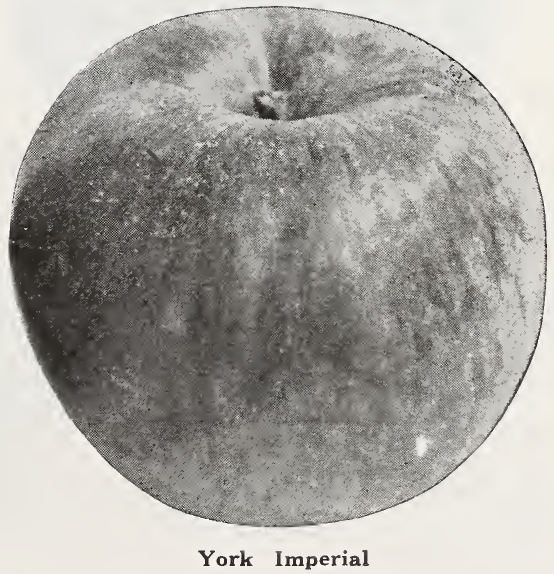




\section{Crab Apples}

A few years ago the crab apple was thought fit only for cider, preserves and jelly, but there are varieties now that command a good price on the market for dessert purposes. They are ornamental when in bloom and when loaded with their highly colored fruits.

BRIAR SWEET-A strong growing, fine orchard tree; an abundant bearer. Fruit pale yellow splashed with carmine; rich and sweet with little or no crab flavor. Season, September.

FLORENCE - Large, handsome; crimson, splashed with darker red; prolific, valuable. September.

GRANT-Large, roundish oblate; yellow, with stripes of deep red, and dark red, almost black on the sumny exposures; flesh white, moderately fine grained, mild, sub-acid flavor. September and October.

HYSLOP-Tree a moderate grower, making a beautiful shaped, thrifty tree; bears young; fruit large, nearly round, flattened at the ends; skin smooth, color dark rich red on yellow ground; flavor very good.

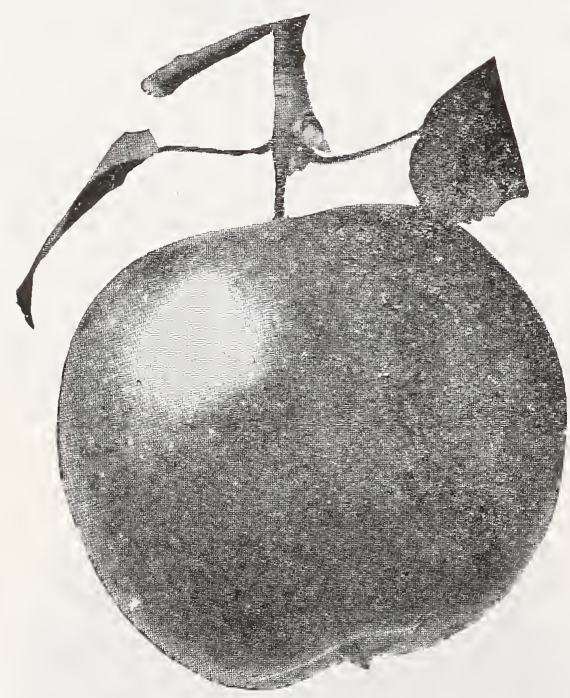

Hyslop

MARTHA -This is one of the best. The ground is bright yellow, nearly over-spread with light bright red. Of good size.

RED SIBERIAN--Large, round, brilliant red on a pale yellow ground; flesh acid and greatly esteemed fo* preserves and jellies.

SOULARD-An improved native of high quality. Fruit very large, yellowish when fully ripe. Partakes strongly of the wild flavor. Perfectly hardy.
TRANSCENDENT-A very strong grower, making a large, beautiful tree; an early and abundant bearer, fruit large, round, skin smooth, color rich yellow, shaded with red. August and September.

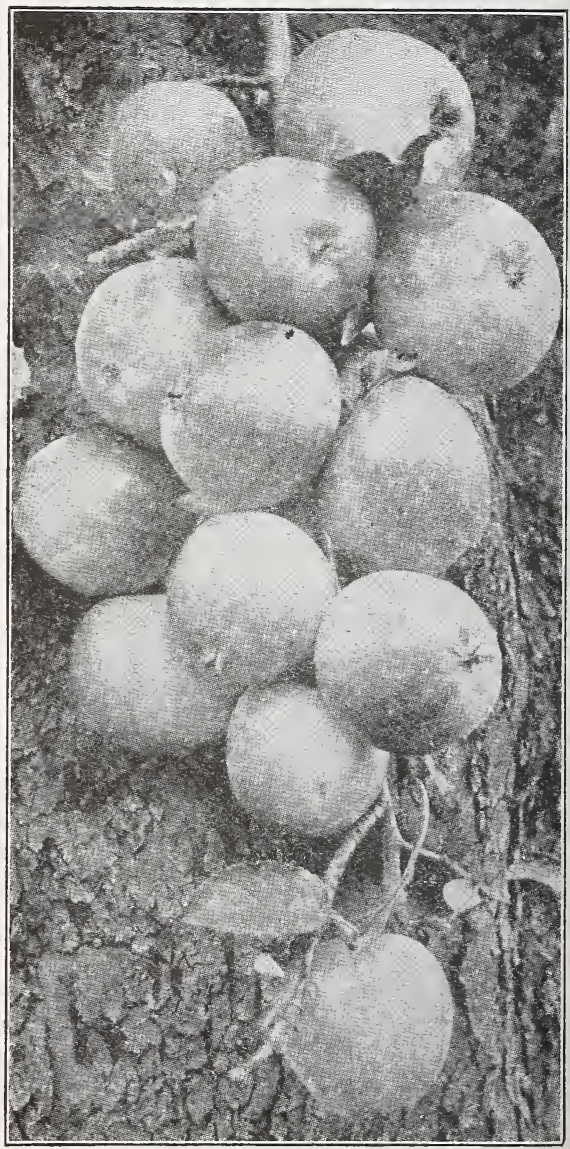

Transcendent

WHITNEY-Tree thrifty, upright grower fruit-large, skin smooth, striped and splashed with carmine; flesh firm, juicy, of pleasant flavor. One of the very best. August.

YELLOW SIBERIAN-Small, round; yellow; flesh yellowish and acid; popular on market for jellies. Tree vigorous and hardy. September. 


\section{Pears}

The soil should be rich and well cultivated. A pear orchard should not be permitted to "go to grass." They should be pruned every year, dwarfs especially. Dwarfs should have low heads and be trained in a pyramidal form, one-half of the previous season's growth being cut off each spring.

Pears succeed best on rather steep hillsides. Plant pears midway on the slope, putting something else on the upper and lower sections. Cultivate sparingly, so as to induce a very slow growth, and let blue grass take the land before the trees come in to fruitage. When blight appears, cut off the affected parts at once and burn them; cut six inches below the lowest blight, to insure taking all infected sap.

\section{Early Varieties}

BARTLETT-Large size, with beautiful blush next to the sun; buttery, very juicy and high flavored; bears early. August and September.

CLAPP'S FAVORITE-Large obovate, ovate; skin thin, pale yellow, marked with pale crimson and lawn colored dots; flesh white, fine grained, juicy, buttery, rich, melting and sweet. Very vigorous, upright grower. August and early September.

KOONCE-Medium to large, very handsome; yellow, one side covered with bright red; flesh juicy, sweet, spicy, good, very earliest. Trees very vigorous, hardy and productive. August.

LE CONTE-Tree very vigorous and productive, fruit large, skin smooth and pale yellow; quality fair; ripens about with Bartlett.

MANNING ELIZABETH - Medium; yellow, red cheek; juicy, melting. No other pear less subject to blight.

WILDER EARLY-One of the very earli. est pears. Size medium, greenish yellow. with a brownish red cheek and numerous dots; flesh white, fine grained, melting, excellent. Always find a ready sale in mar ket. Largely grown by commercial orchardists. Tree bears good crops early and annually. December and September.

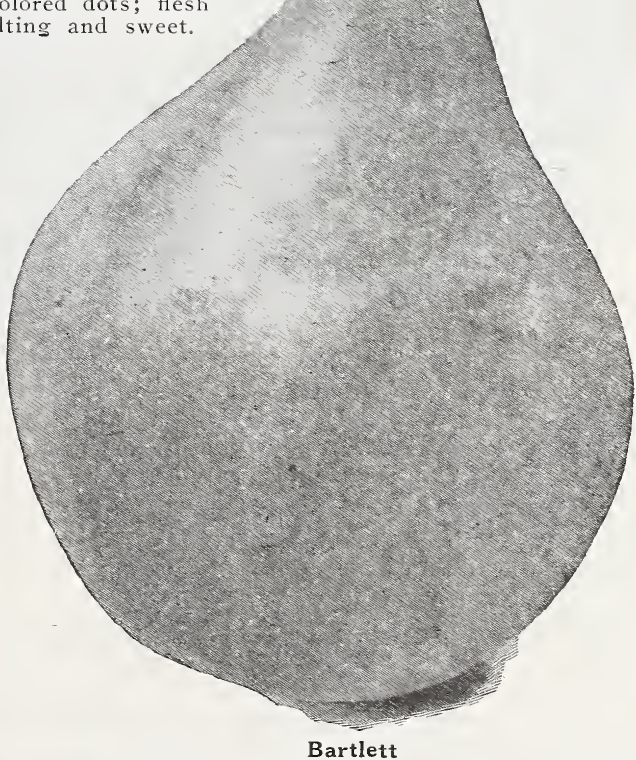

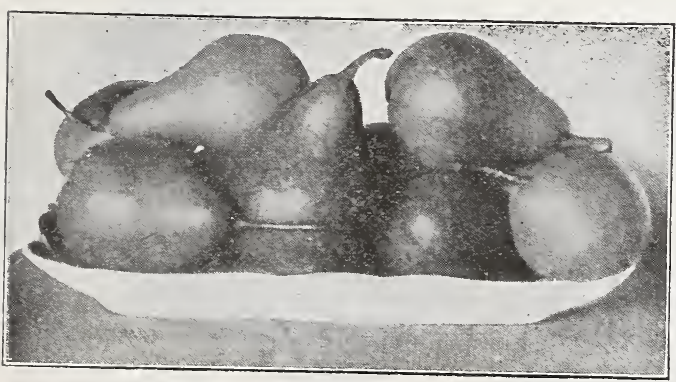

Duchess D'Angouleme

\section{Autumn Varieties}

BEURRE D'ANJOU - Large, obtuse pryaform; dull, yellowish green, sometimes with a dull, reddish cheek; flesh whitish, juicy, melting, with a brisk perfumed flavor. Vigorous and hardy. Octo. ber.

DUCHESS D'ANGOULEME - V e r y large, oblong, obovate, dull greenish yel low, flesh white, very juicy, buttery, with a rich, excellent flavor. Tree a strong grower. October. 


\section{Autumn Varieties-Continued}

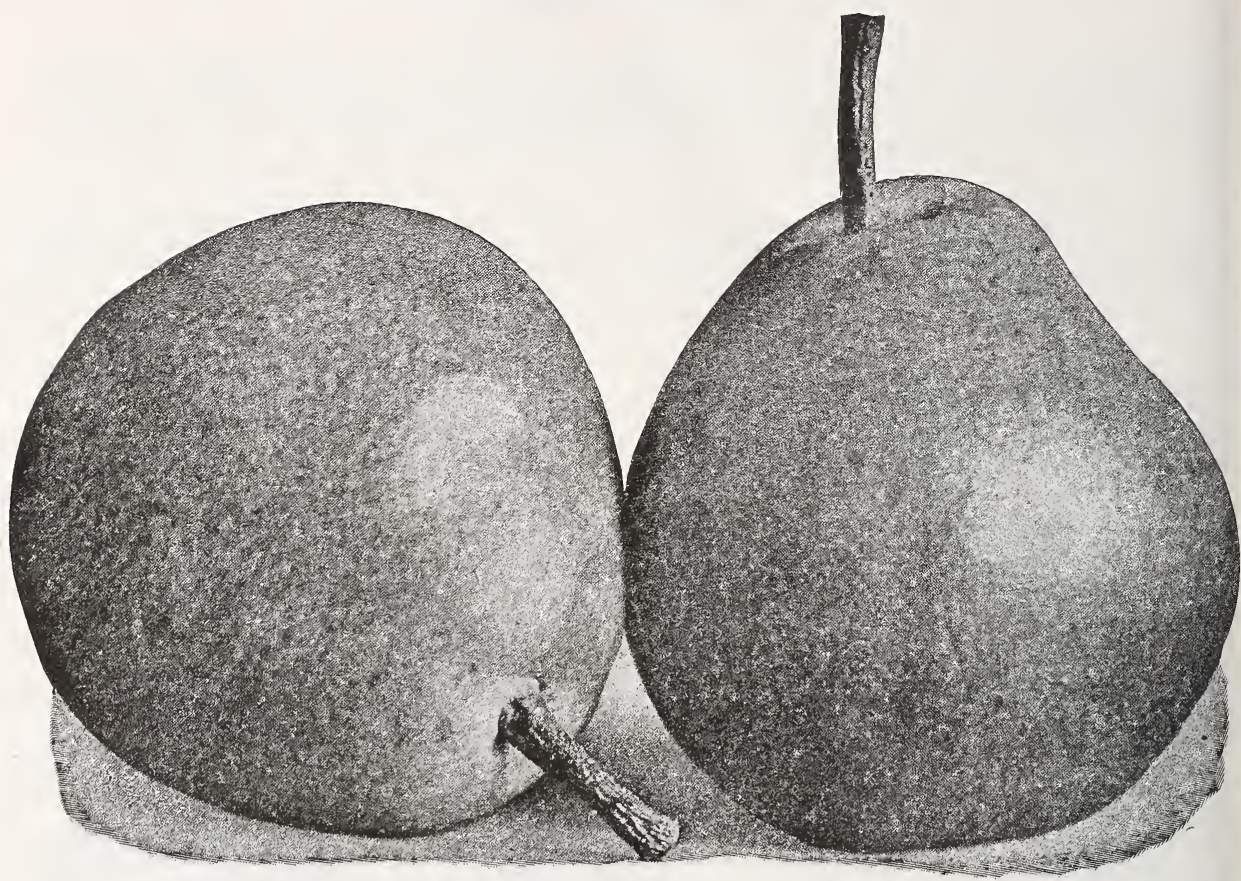

Kieffer

FLEMISH BEAUTY-Large, beautiful, juicy, melting, rich and fine; good bearer; one of the hardiest and does well nearly everywhere. September and October.

GARBER-Very large, oval, narrowing at both ends; yellow as an orange; flesh whitish, juicy, sweet and very plessant. Tree an upright grower with heavy, dark green foliage. September.

HOWELL-Large, light, yellow, red-cheeked; rich and sweet. Tree upright, free grower; early and prolific. September and October.

IDAHO-A native of Idaho. Fruit golden yellow, with red cheek. Shaped more like an oblong apple than a pear. Delicious flavor. October to December.

KIEFFER-Large; golden yellow, often blushed in the sun; juicy and melting. One of the best for canning and preserving; the most profitable to grow. Tree healthy, hardy and vig. orous. Does not succeed on quince, therefore no dwarfs should be planted. Kieffer receives more praise and condemnation than any other. It is liable to overbear, therefore special pains should be taken to thin the fruit.

LINCOLN CORELESS-Practically coreless; late. Fruit should be picked when green to escape the early frosts. Large, quality good. Good bearer, hardy.

SECKEL-Small, skin rich, yellowish brown; flesh very fine grained; sweet, juicy and pleasant. Best for its size. September and October.

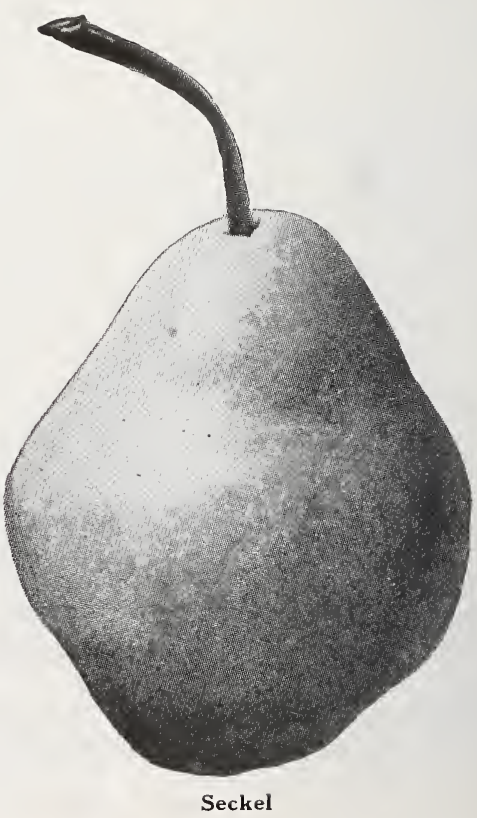




\section{Plums}

The plum delights in a cool, not too dry situation, and good rich soil. Plant trees 10 to 15 feet apart, in rows. The varieties we offer have been thoroughly tested, and are standbys. These may be relied upon to furnish crops of this profitable and delicious fruit.

\section{European Varieties}

BRADSHAW-Fruit large; dark violet red; flesh yellowish green; juicy and pleasant; productive. Vigorous. Middle of August.

DAMSON (Europe)- Small; black, with thick blue bloom; free; flesh juicy, but rather tart; best for kitchen and market. Tree enormously productive and hardy. September.

GERMAN PRUNE-Very large, long, oval; purple, with a thick blue bloom; flesh green, firm, sweet, pleasant and separates freely from the stone. Tree bears enormous crops, hanging late; vigorous. September.

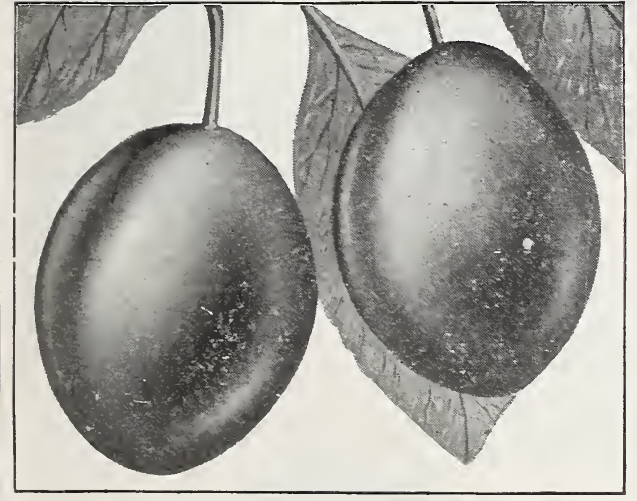

\section{German Prune}

GREEN GAGE (France)-Medium; greenishyellow; semi-cling; flesh juicy, rich and delicious; one of the best for dessert. Tree slow grower. September.

LOMBARD - Tree vigorous, hardy and productive; fruit of medium size, roundish oval, slightly flattened at the ends; skin of a delicate violet-red, paler in shade; flesh deep yellow, juicy and pleasant. August.

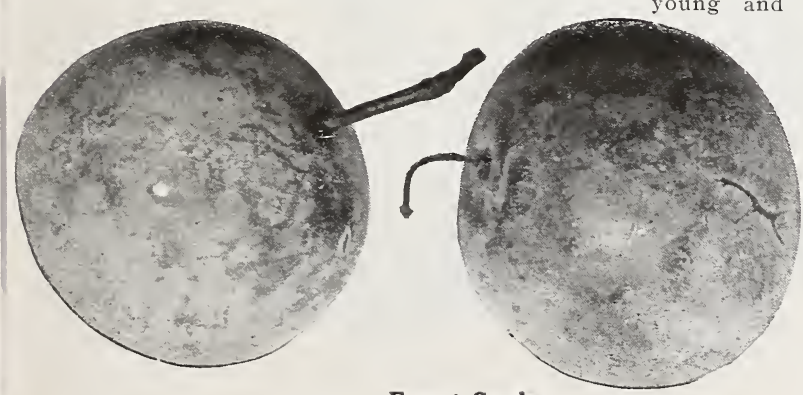

Forest Garden

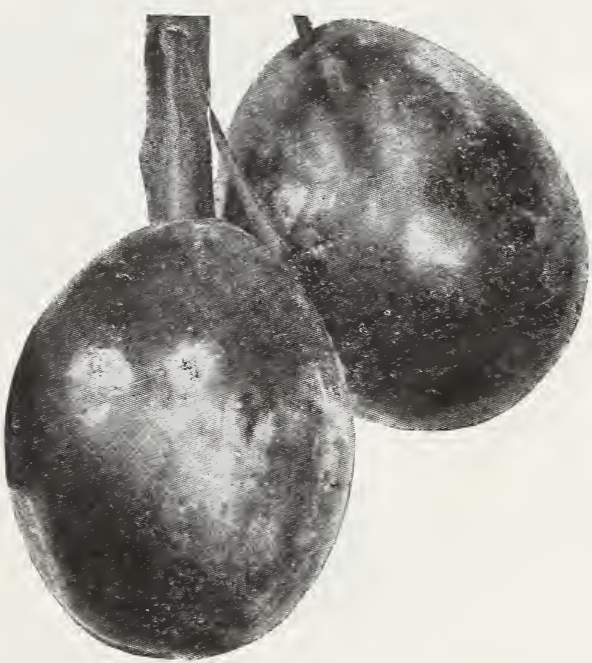

Lombard

SHIPPER'S PRIDE-Size large; color dark purple; flesh firm and excellent. September.

SHROPSHIRE DAMSON-A plum of fine quality. The flesh is amber colored, juicy and sprightly. Very productive and a valuable market variety. Freestone. September.

YELLOW EGG-Tery large; egg-shaped; excellent for cooking; good and productive; vig. orous. Last of August. Splendid variety for nearby market.

\section{Native Varieties}

DE SOTO-Resembles Miner in form and color, but two weeks earlier. Fine for eating or canning. Tree a moderate grower; bears young and profusely; hardy north. Is best planted on moist rich ground and the fruit thinned. Use this variety for fertilizing.

FOREST GARDEN-A strong growing tree; needs a little attention to keep tree in shape to avoid splitting and breaking of limbs. A profuse bearer and perfectly hardy; nearly round, mottled red and yellow, rich and sweet. August.

HAMMER - Large, oblong, light red, of fine quality; profusely fruitful; season late; fine for canning or market. 


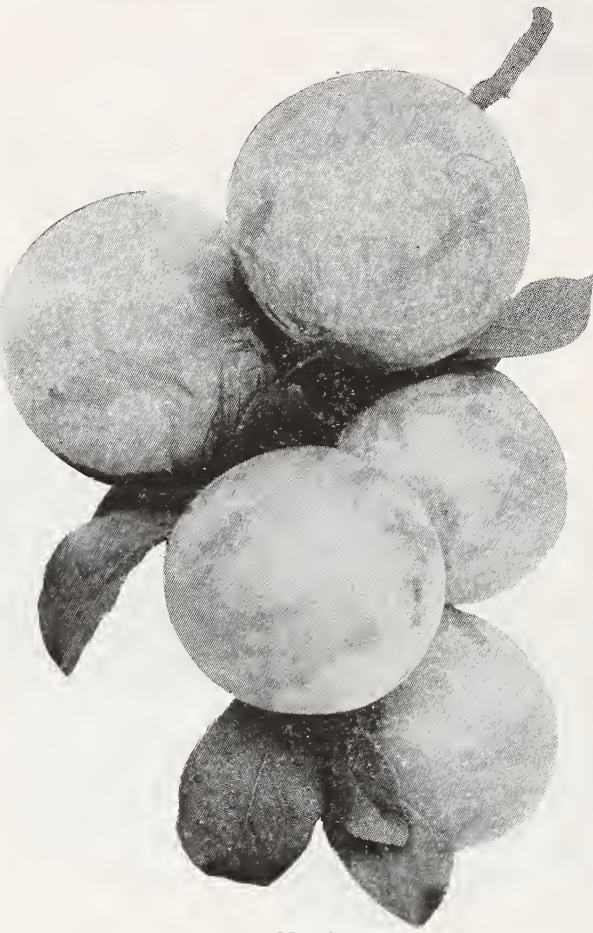

\section{Native Varieties-Continued}

HAWKEYE-One of the best. Large, color light mottled red, superior quality, firm; carries well to market. Tree hardy, thrifty; annual bearer. A splendid fertilizer. September.

COMPASS CHERRY-Small, purplish red, with large pit, flesh yellow and very good for cooking. The original cross of Minor Plum and Sand cherry.

POTTAWATTAMIE - Tree of good grower, hardy; color a yellowish red turning to bright red when fully ripe; skin thin, clear and tough. First fruit begins to ripen late in July; quality fairly good.

STODDARD-One of the largest of the native plums originated in Iowa. It is a light pinkisi red color, very handsome, with a tough, sweet skin. Quality fair.

SURPRISE-Prune-shaped, dark red. Long keeper, therefore valuable for market. Ripe from September 1 to 10 . Tree a thrifty, upright grower; hardy in the nortinest and productive. A fine tree in orchard.

WEAVER - Large, purple with a blue bloom, very prolific; a constant and regular bearer and of good quality. Tree very hardy. August.

WILD GOOSE-The most popular fruit with some fruit growers. Tree a vigorous, upright grower; fruit medium to large, rich golden yellow, shaded with red; flesh yellow and juicy; flavor rich and good.

WOLF-Fruit large, a perfect freestone. As to qual ity we find them superb for cooking and for serving with sugar as we use peaches. Tree a good grower; hardy. August.

WYANT-Large, round, oblong, dark red; flesh firm; freestone; and of excellent quality. Native of Iowa and hardy.

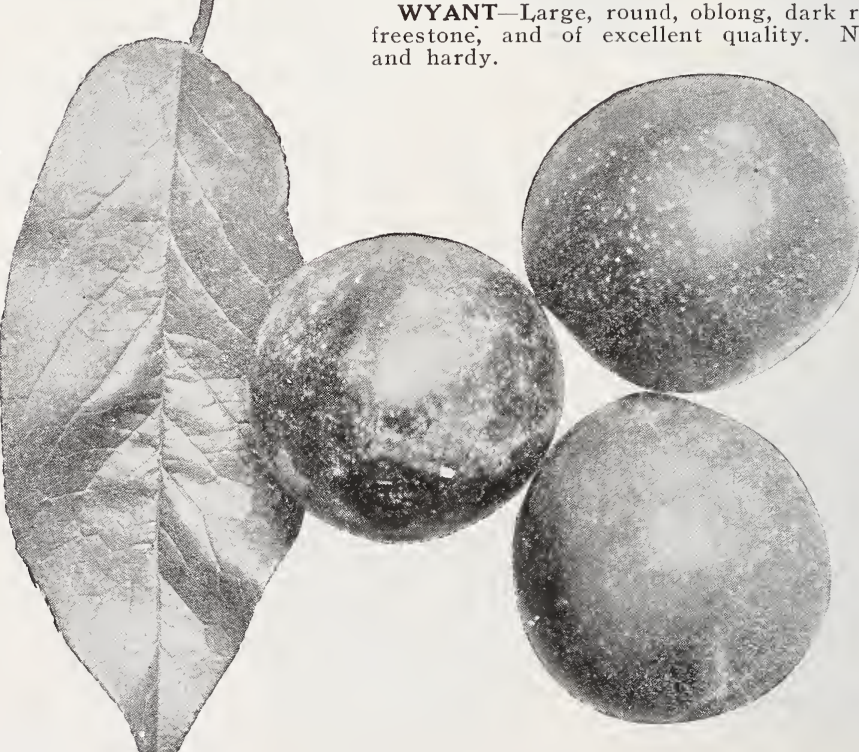




\section{Japan Varieties}

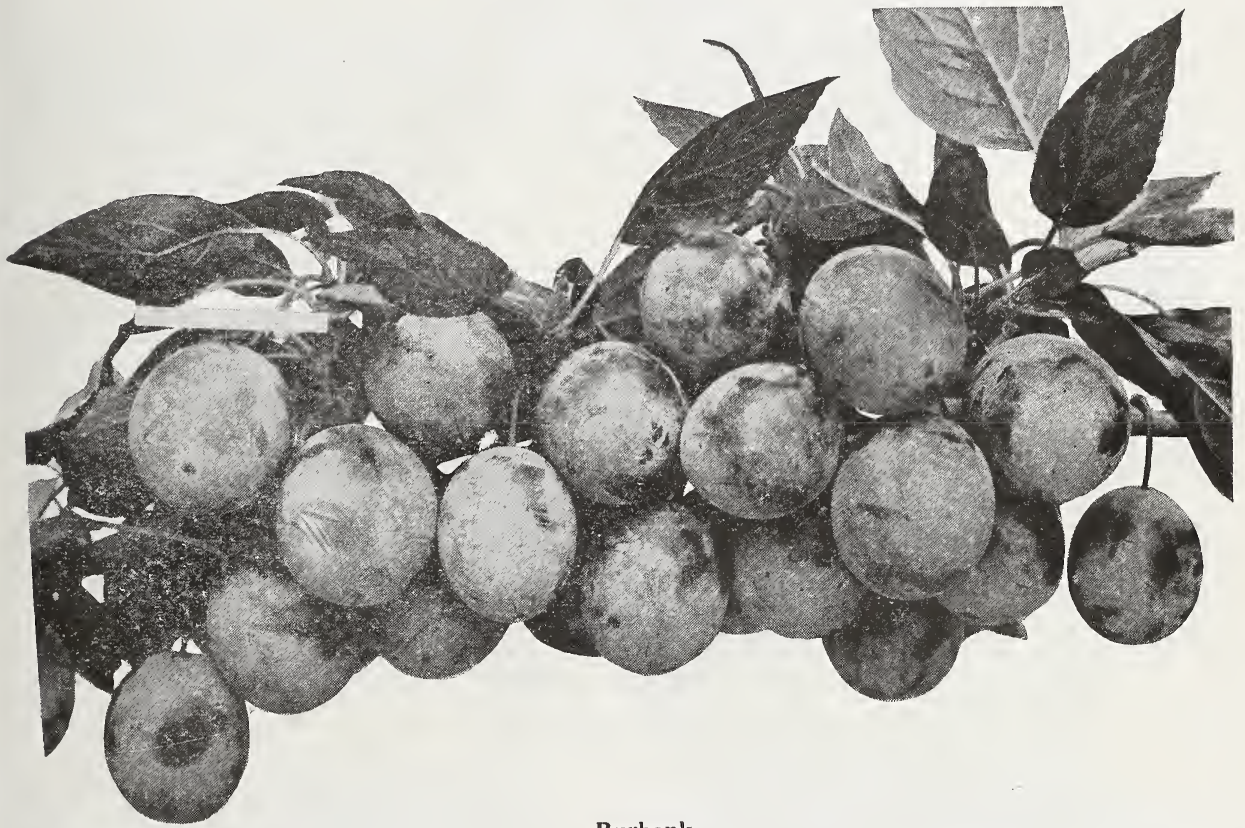

Burbank

ABUNDANCE - Large, roundish; freestone; amber, turning to a rich cherry color with a whitish bloom; flesh light yellow, juicy, tender, sweet and excellent, vigorous and very productive. August.

BUR.BANK - Iarge, nearly globular; clear cherry red with thin lilac bloom; flesh deep, yellow; rich, very sweet, with a peculiar and agreeable flavor. Vigorous and a very early bearer. Last of August.

SATSUMA (Blood)-A fine, large plum, delicious for canning and a grand market sort; nearly round; flesh is solid, juicy and of fine quality; pit little larger than a cherry stone; tree a strong, vigorous grower. Will keep for from one to two wceks after picking. Yields well.

WICKSON-A remarkably handsome, very large, deep maroon red plum.

\section{Hybrid Varieties}

HANSKA-Beautiful color, bright red, with heavy bloom; flesh firm, yellow and of good quality; fragrant; apricot flavor; tree tall, rapid grower; pit small.

SAPA-Much like Oxheart cherry, dark flesh and juice. Fine quality. Five-foot trees at three years bear 1 to $1 \frac{1}{2} / 2$ bushels and keep it up. Every home in the country should possess from one to a dozen of these wonderful trees.

OPATA-Flesh firm, greenish with pleasant flavor. Pit small; season early; is strong grower and heavy bearer.

TOKA-Similar to the Hanska, of same parentage; tree remarkably strong and vigorous grower, making a model tree; early and heavy bearer of handsome fruit.

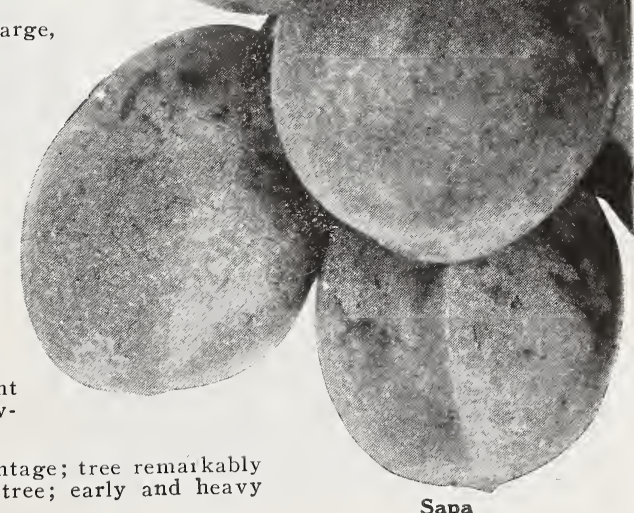




\section{Cherries}

Cherry culture has been a success when proper attention has been given to the selection of varieties and their culture. The hardy, thrifty varieties of the Morello type may be freely planted with confidence of profitable results. The cherry tree should be planted in a naturally dry soil or the soil should be well drained, so that water may not remain near the roots for any considerable time.

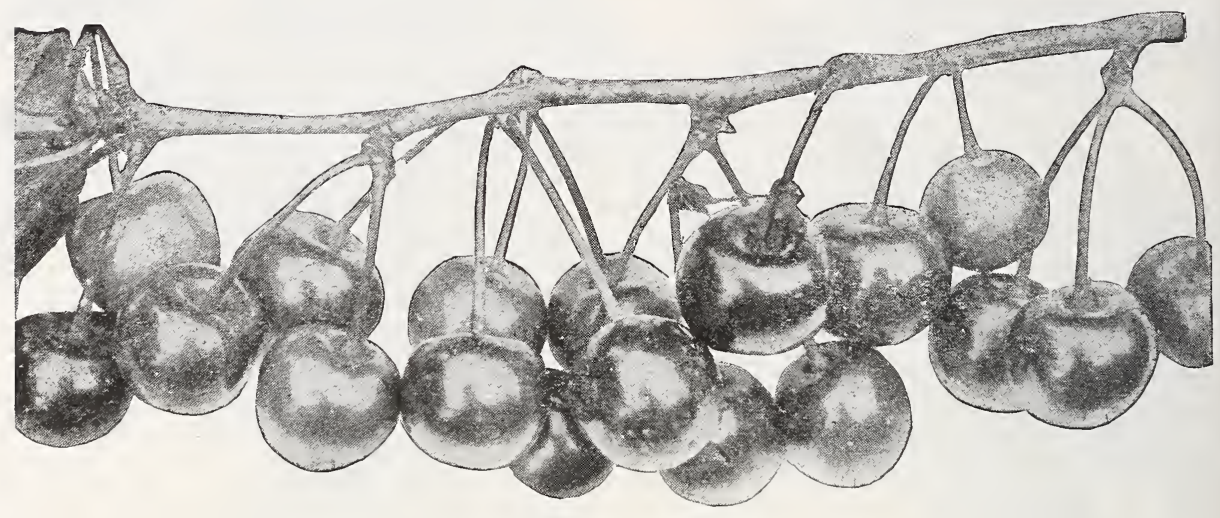

Large Montmorency

\section{Duke and Morello (Sour)}

DYEHOUSE - This variety partakes both of the Morello and Duke wood and fruit. A very early and sure bearer; ripens a week before Early Richmond, is of better quality and productive. Free. May and June.

EARLY RICHMOND-Everywhere the most popular. Tree strong, thrifty grower, making a large, symmetrical head; fruit medium size, dark red, melting, juicy; sprightly acid flavor and especially valuable for cooking purposes; tree an early and abundant bearer. Season last of May and first of June.

ENGLISH MORELLO - Tree moderate grower, hardy; an early and great bearer; the most valuable of the late varieties. Fruit large, round; skin dark red, becoming nearly black when fully ripe; flesh dark red, tender, juicy and of a pleasant sub-acid fla. vor when fully ripe. July.

LARGE MONTMORENCY - (Large Mont morency.) A fine, large, light red cherry of the Richmond class, but larger and more solid; a more upright grower, equally hardy and productive. Second only to Early Richmond in value. Ripens ten days later.

OSTHEIM - Tree medium size, with round, compact top like English Morello; bears early and abundantly. Fruit medium size; almost black when fully ripe; juicy, rich, almost sweet. For eating from the hand it is at the head of our list of hardy cherries. Season late.

WRAGG-Originated in Iowa. Medium to large in size, long stem, dark purple when fully ripe. A variety well adapted for the prairie regions of the Northwest. Appears identical in tree and fruit with English Morello, but is claimed to be a new variety. Valuable late cherry. July.

\section{Heart and Bigarreau (Sweet)}

BLACK TARTARIAN - Very large, bright, glossy black; half tender, juicy, rich and fine. Tree a rapid grower and good bearer. Last of June and first of July.

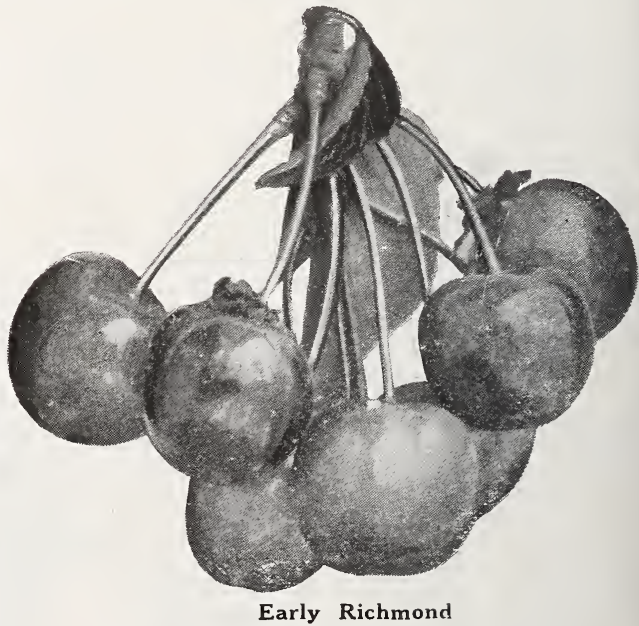

GOVER.NOR WOOD-Large; light yellow and bright red; nearly tender, juicy, sweet, rich and delicious. Tree vigorous and productive. Middle to last of June.

WINDSOR - The fruit is large, flesh remarkably firm, sweet and of fine quality. Tree hardy and prolific. Middle of June. 


\section{Peaches}

Peach trees should be planted 16 to 18 feet apart. Cut weak shoots back about one-half and strong ones about one-third, but see that there is left a sufficient supply of fruit buds. Sickly and superfluous shoots should be cut out clean. The fruit is borne on wood of last season's growth, hence the necessity of keeping up a good supply of vigorous annual shoots all over the tree. Young trees should be well mulched every spring.

ADMIRAL DEWEY (F.)-A perfect freestone, of fine size, form and color, with delicious yellow flesh that is yet firm enough to ship well. The tree is a strong, hardy, symmetrical grower and produces well. The best early yellow freestone. July.

ALEXANDER (S. C.)-Large size, handsome and regular in form, with deep maroon shade, covered with the richest tint of crimson, rich and good in quality, with a vinous flavor; arlheres to the stone. Last of June.

BANNER (F.)-Large, yellow, with crimson cheek, flesh firm, yellow, rich, excellent; keeps and ships as well as any peach on the market. Has been grown in Cansda for fifteen to twenty years and found to proluce good crops yearly through several seasons when other sorts failed. Best late market variety. October.

BOKHARA (F.)-Raised from seed procured in Bokhara, Asia. It has been fruited in the Northwest for years and found to be one of the hardiest peaches known there. Tree has stood 28 degrees below zero with but little injury to the tips, and produced fair crops. Fruit, large, yellow, with red cheek, of good quality, perfect freestone; skin tough, a fine shipper, August.

CHAMPION (F.)-The earliest freestone and a first-class shipper. Bears full crops when others fail. In comparison with the bountiful yield of all of the best kinds, it is of all of them the champion. Size large; flavor delicious, juicy, sweet, rich, excelling all other varieties; very handsome in appearance, creamy white with red cheek; very hardy; season earliest.
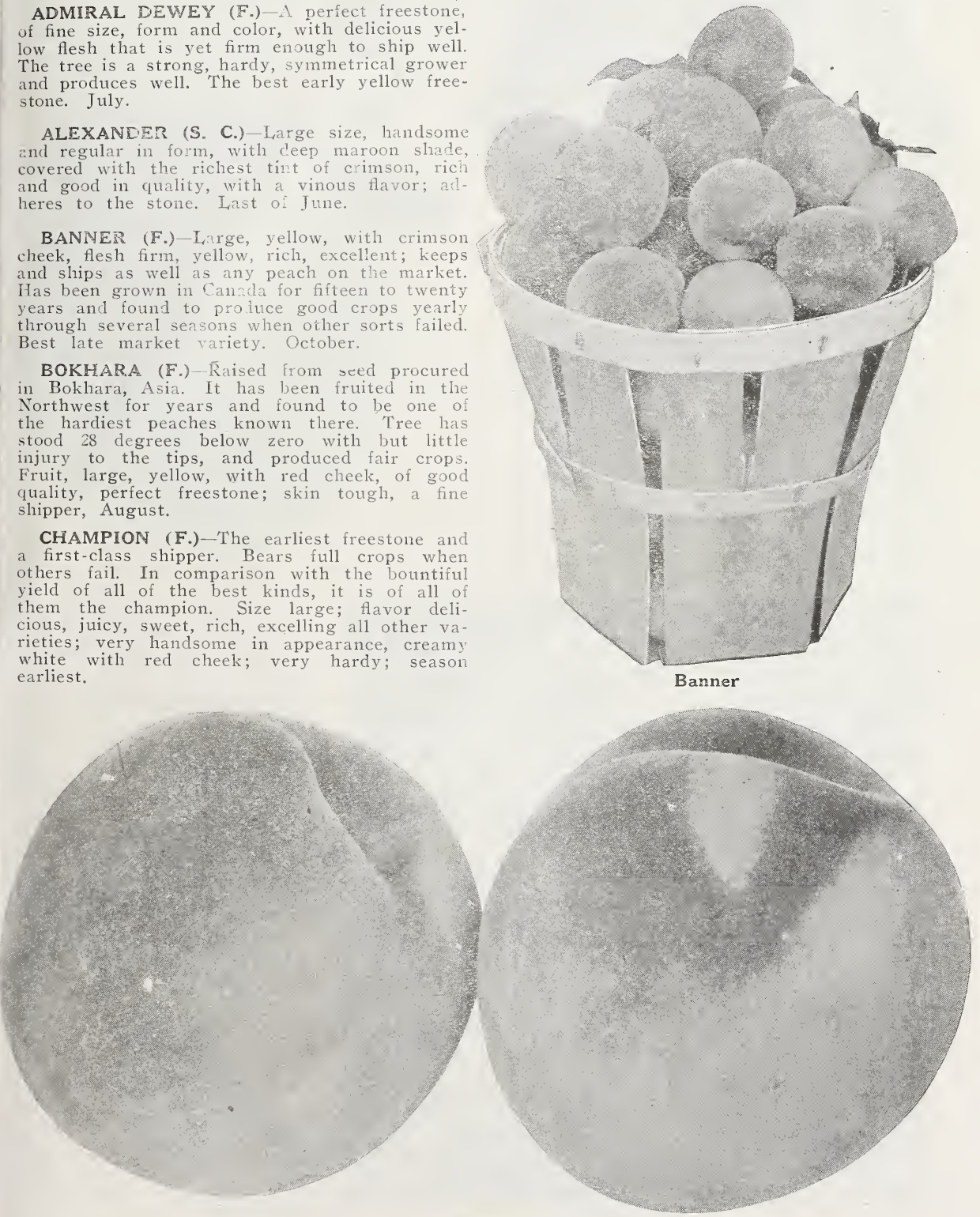

Champion 


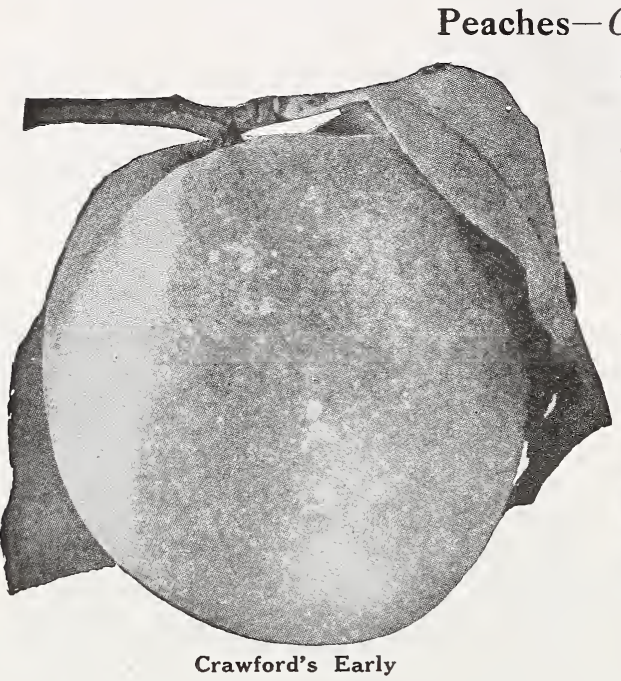

CRAWFORD'S EARLY (F.) - Fruit very large, oblong; skin yellow, with a fine red cheek; flesh yellow, juicy, sweet and excellent. Wonderfully productive and hardy. Freestone. Last of August.

CRAWFORD'S LATE (F.)-Fruit of the largest size; skin yellow or greenish yellow, with dull red cheek; flesh yellow; productive. One of the finest late sorts. Freestone. Last of September.

CROSBY (F.)-Rich orange yellow with blush, freestone, pit small. Flesh yellow, juicy and

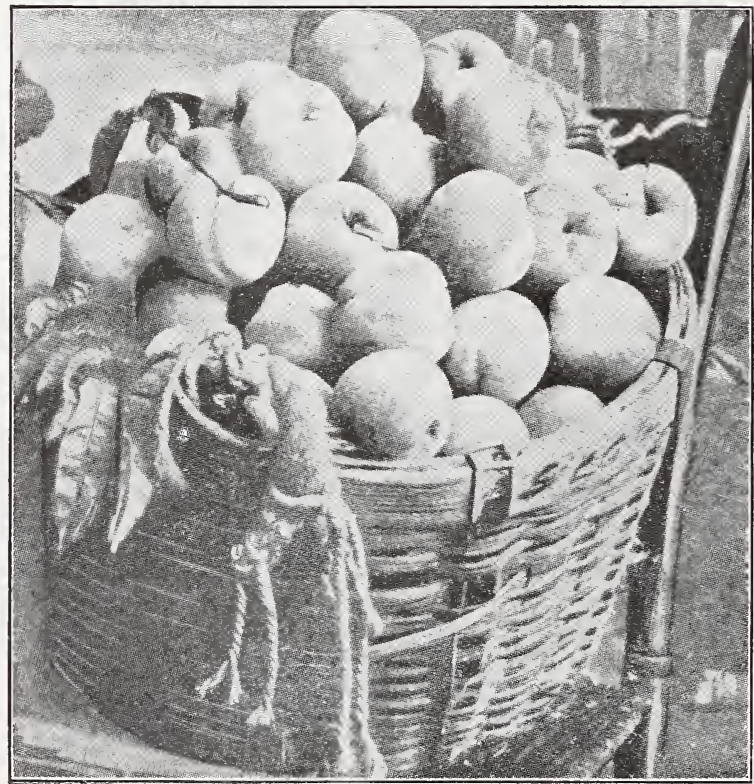

Elberta sweet. Tree low, spreading; willowy habit of growth. Ripens before Crawford's Iate.

ELBERTA (F.) - Large, yellow with red cheek. Of excellent quality; flesh yellow and melting; freestone. The market peach of America.

FITZGERALD (F.)-An improved Early Crawford, being fully equal to it in size, quality and color. The tree commences bearing young, is productive and one of the hardiest. Fruit large, brilliant color, bright yellow, suffused with red; flesh deep yellow, best quality. Early September.

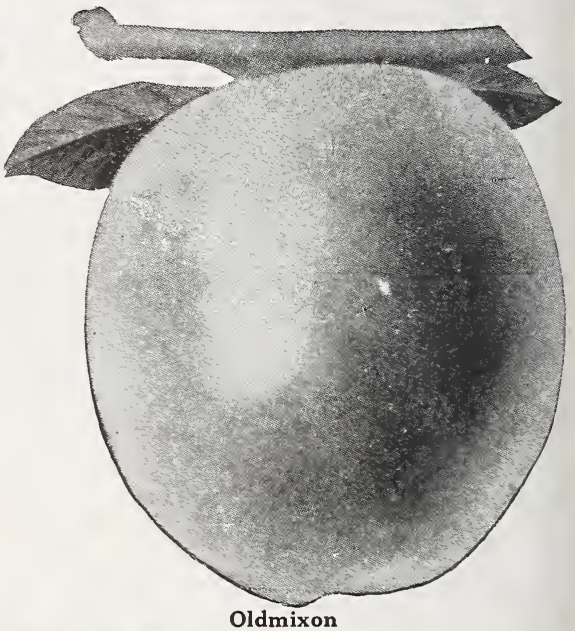

ixon

HEATH CLING-Large, oblong, white, slightly tinged with red in the sun. Fruit tender, rich, melting, luscious. September 15.

OLDMIXON (C.)-One of the old standard sort. Strong, upright grower, needing heavy annual shortening. Fruit large, round, somewhat elongated. Flesh firm and of good quality. Augųst.

SNEED (S, C.)-Fruit medium to large, greenish white, blush on sunny side; juicy and good, July. Not reliable North, though desirable as a very early bearer.

TRIUMPH (F.)-Earliest yellow fleshed, wi ${ }^{2} \mathrm{~h}$ good eating and shipping qualities. Sure and abundant bearer; strong, vigorous grower. Fruit good size, yellow, with red and crimson cheek.

WONDERFUL (F.) - Originated in New Jersey. Very large, yellow with red cheek; flesh yellow, highly flavored and firm; bright red at the pit, which is small and parts freely from the flesh. Good keeper. October. 


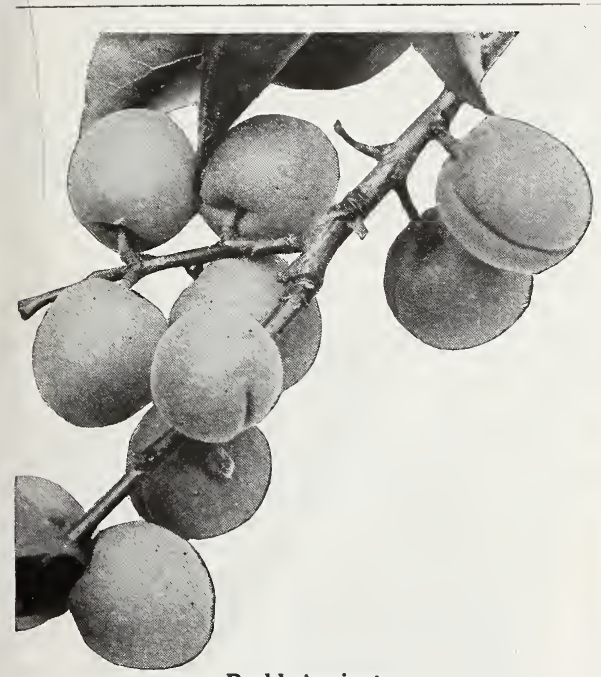

Budd Apricot

\section{Apricots}

ALEXANDER-Russian, an immense bearer. Fruit large, oblong, yellow, flecked with red; sweet and delicious.

BUDD-Russian. Large, white with red cheek; sweet and juicy; strong grower, good bearer. Late.

GIBB-Russian. Medium, yellow, sub-acid, rich and juicy, the best early sort.

MOORPARK-One of the largest and finest apricots. Yellow with red cheek. Flesh orange sweet, juicy and rich; parts from the stone. Very productive.

RUSSIAN-A new variety of recent introduction; valuable on account of extreme hardiness of trees and fine quality of fruit.

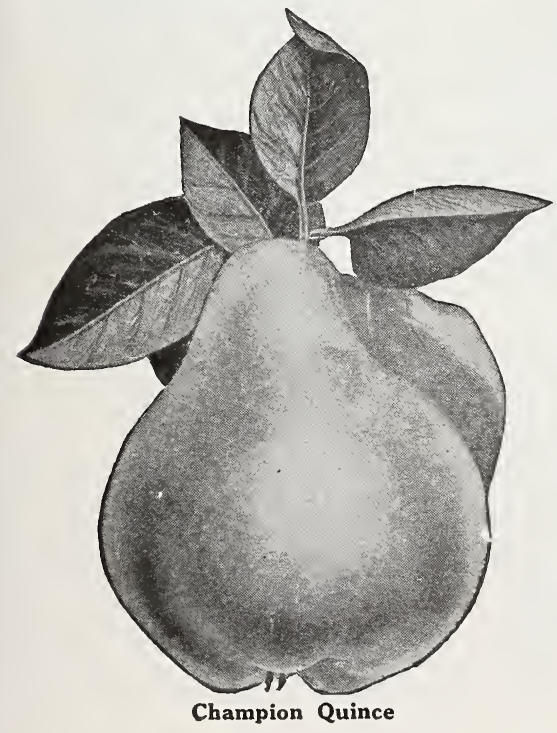

\section{Mulberries}

The mulberry is not only valuable as an ornamental shade tree, but the fruit is well worthy of a place in every collection. Plant in deep, rich sandy loam. The tree requires little or no pruning and is of easy culture.

DOWNING'S EVERBEARING-This delicious variety produces a large fruit of a dark, purplish black color; flesh juicy, rich, sprightly, delicious.

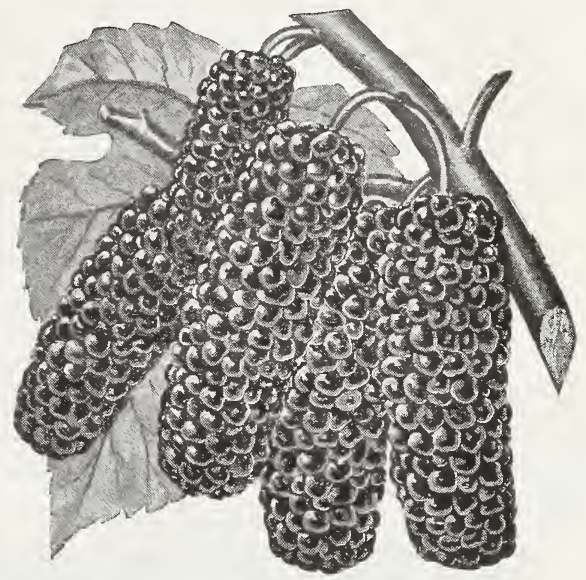

Downing's Everbearing Mulberries

Very productive and ripening its fruit in succession for a long time. Not hardy North.

NEW AMERICAN-Largest fruit, black; delicious flavor; a very attractive lawn tree, with very large leaves. Of rapid growth. Hardy.

RUSSIAN-Good shade and ornamental tree, rapid grower, excellent wind and snow break; most valuable to supply the native birds, thus keeping them from the most precious fruits. Fruit of little value.

\section{Quinces}

APPLE or ORANGE-Large, roundish; yellow; cooks tender and is of excellent flavor. Valuable for preserves and flavoring. Productive. September and October.

BOURGEAT-Very large; golden yellow, tender, good flavor. With carefu! handling it keeps in a good cellar until spring. The tree exceeds all others in fruitfulness and sometimes bears when 3 or 4 years old. October.

CHAMPION-Fruit large, fair and handsome. Tree bears abundantly while young. Flesh cooks as tender as an apple and without hard spots or cores; flavor delicate. The most valuable of all.

MEECH PROLIFIC-The most profitable of all known varieties. Ripens between the Orange and the Champion. Bears early, quality good, and size large.

REA'S MAMMOTH-A very large, fine variety of the orange quince. Strong grower and productive. 


\section{Grapes}

Annual and careful pruning is essential to the production of good grapes. The roots cannot bring to maturity a fine crop of fruit if they are called upon to carry too much wood. Late in the fall is the best time to prune, when the vines are dormant.

\section{Red Varieties}

AGAWAM-Bunch large, shouldered; berry large, reddish brown, tender, vinous and of excellent flavor. Very vigorous and productive. Vine hardy and one of the best of its class.

BRIGHTON-Bunch large, shouldered; berries mediur. to large, round, dark red, tender, very little pulp, sweet, juicy, slightly aromatic and very good. Ripens early.

DELAWARE-The bunches are small, compact, and sometimes shouldered; berries are small with thin but firm skin; flesh juicy, very sweet and refreshing and o the best quality for both table use and for wine. Ripen with Concord or a little before; vine is hardy, productive and a moderate grower.

SALEM-Bunch large and compact; berry large, of a light chestnut or Catawba color, thick skin, perfectly free from hard pulp; very sweet and sprightly with a most exquisite aromatic flavor; as early as Worden; keeps well.

VERGENNES-Berries large, holding firmly to the stem; light amber, rich and delicious. Is an excellent late keeper.

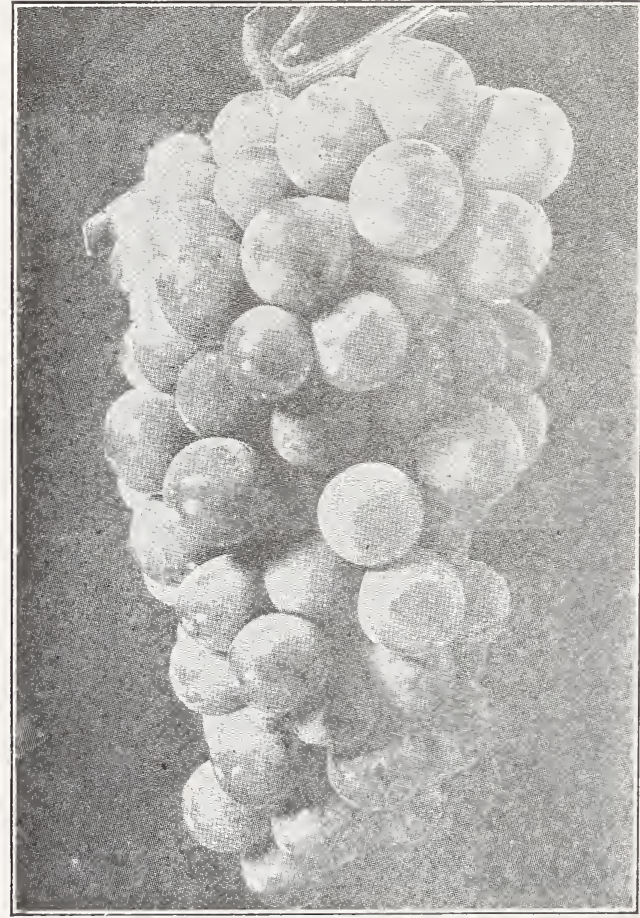

Delaware

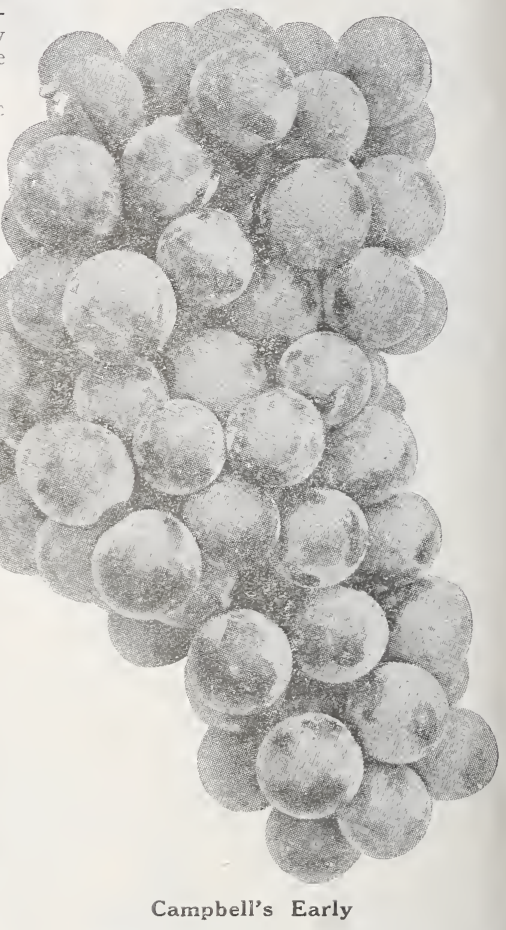

WOODRUFF - A handsome, profitable market sort; vine vigorous, productive; iron-clad constitution. Bunch and berry large, attractive, ripens early; fair quality, long keeper, good shipper. In most sections the best red market grape for mair $_{1}$ crop.

\section{Black Varieties}

BETA-A small desirable grape that will prosper as far north as North $\mathrm{Da}$ kota, often making a growth of 15 or 30 feet in a single season.

CAMPBELL'S EARLY-A new, very large and fine early grape, black; strong, vigorous, hardy vine with thick, healtlyy leaves; clusters very large, usually shouldered, compact and handsome; berries large, nearly round, black, rich, sweet, very good; skin thin; seeds few and small, parting easily from the pulp; a good shipper. Ripens very early, but remain sound on the vines for many weeks. This makes it one of the most satisfactory and profitable market scirts to grow. 

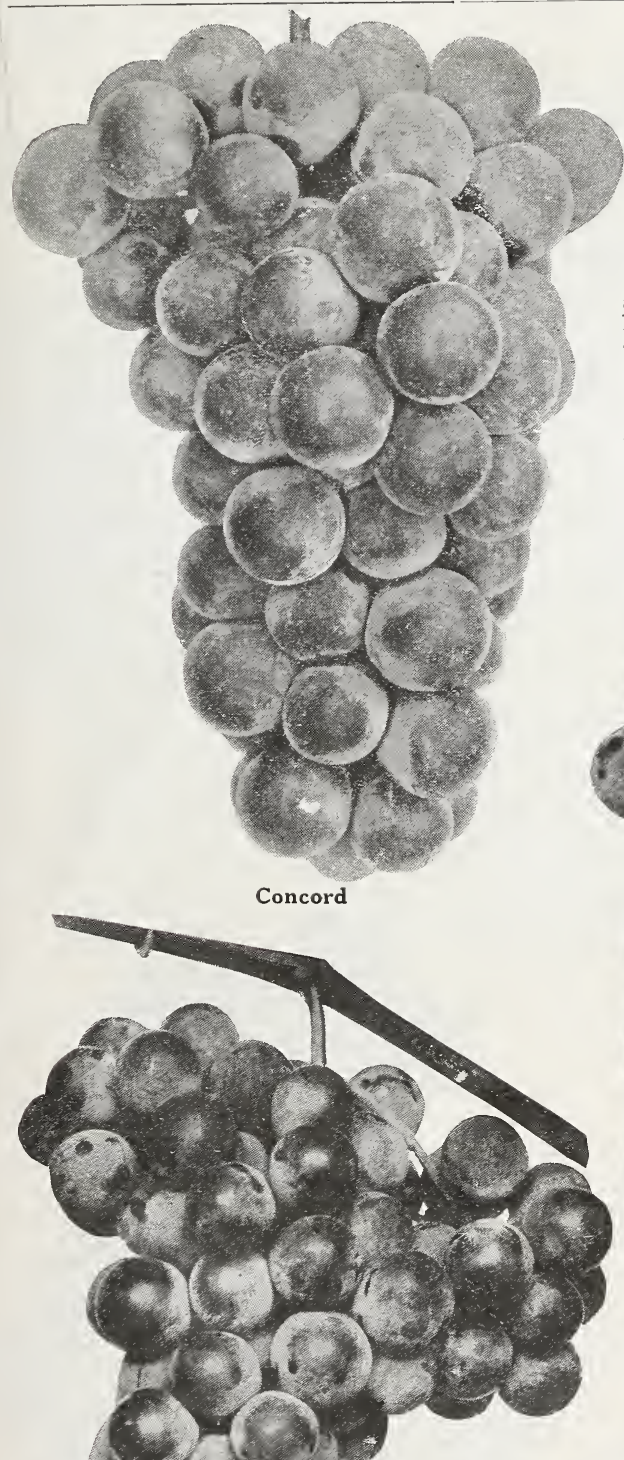

CHAMPION-Bunches large and compact; berries large, covered with a rich bloonı; poor in quality; vine a strong and healthy grower and a good bearer; profitable for market on account of its earliness.

CONCORD-One of the most Dopular and reliable varieties we possess; bunch large, compact and shouldered; berry large, round, almost black with blue bloorn, juicy, buttery and very sweet.

MOORE'S EARLY - A large grape, ripening a week earlier than Concord; good grower; berries large, good quality, and makes a moderate yield; very valuable as an early grape.

WORDEN-Seedling of the Concord, which it greatly resembles in appearance and flavor, but the berries are larger. The fruit is said to be better flavored and to ripen several days earlier. These qualities will give it the foremost rank among native grapes.

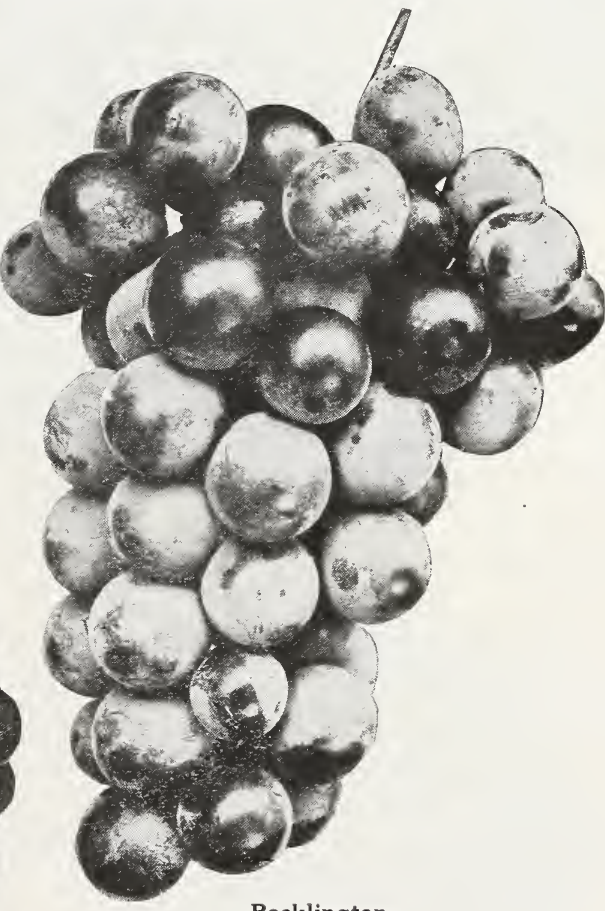

Pocklington

White Varieties

MARTHA-Bunches and berries of medium size, greenish white, with a thin bloom; flesh tender, with very little pulp, juicy, sweet and rich, hardy and productive. Ripens with Concord.

NIAGARA-Occupies the same position among the white varieties as Concord among the black. Bunch and berries large, greenish white, changing to pale yellow when fully ripe. Skin thin but tough; quality much like the Concord.

POCKLINGTON-Seedling from the Concord. The vine is thoroughly hardy both in wood and foliage; it is a strong grower, never mildews in vine or foliage. The fruit is a light golden yellow, clear, juicy and sweet to the center, with little or no pulp; bunches very large, sometimes shouldered; berries round, very large and thickly set. Ripens with the Con-

Moore's Early cord. 


\section{Raspberries}

Plant three and a half feet apart in rows four feet apart. Thin to four or five good canes in a hill; cut out old canes as soon as through fruiting.

\section{Red and Purple Cap Varieties}

CUTHBERT-Cane tall and vigorous, berries large, conical, rich crimson and very handsome; best quality and carries well; very productive.

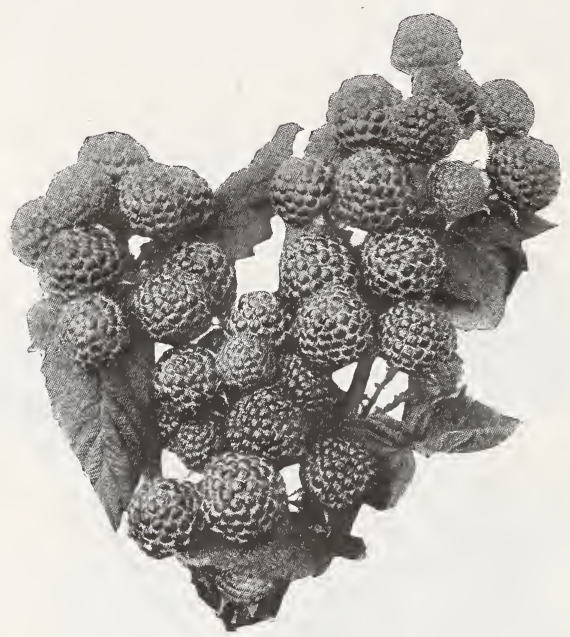

Loudon

COLUMBIAN-The Columbian is a new variety of the Shaffer type, of remarkable vigor and productiveness. Not very hardy and propagates from tips. Fruit very large, often an inch in diameter, shape somewhat conical, color dark red bordering on purple; adheres firmly to the stem and will dry on the bush if not picked; seeds small and deeply imbedded in a rich juicy pulp with a distinct flavor of its own. Succeeds wherever red sorts do well and promises to become the leading variety. A most delicious table berry.

HAYMAKER-Purple cap. A splendid shipper and canning berry; does not crumble; excellent quality; very productive; plants vigorous and hardy.

KING-Probably this is the best variety now growing. The cane is hardier than found in most varieties and it is a medium berry of large size and good quality.

LOUDON-The superior points of this excellent red raspberry are vigor of growth, large fruit, beautiful rich, dark urimson color; good quality and marvelous productiveness and hardiness. It stands shipping better than any variety and will remain on the bushes longest without injury.
MARLBORO-A profitable early market berry, with large, light crimson fruits of good quality and firmness. Very hardy and well suited to the North.

MILLER-This is our best early sort and the cane is hardier than most of the others. The berry is of good size and of fine quality.

ST. REGIS EVERBEARING-The new everbearing variety. It gives a crop of fruit all summer and autumn fruiting on the old canes in generous quantities until late in August. By this date berries begin to ripen on the young canes and continue until late in autumn. Berries are a bright crimson of large size and of surpassing quality, rich, sugary with full raspberry flavor. It succeeds upon all soils, whether light and sandy or cold heavy clay and the canes are absolutely hardy.

TURNER-This is our oldest early variety and the berry is not as large as Miller and not quite so firm.

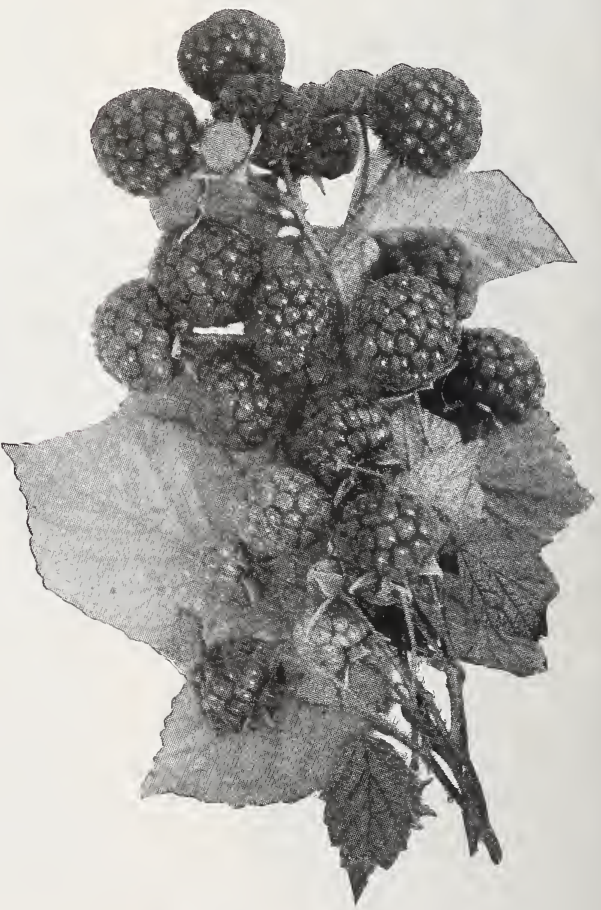

St. Regis Everbearing 


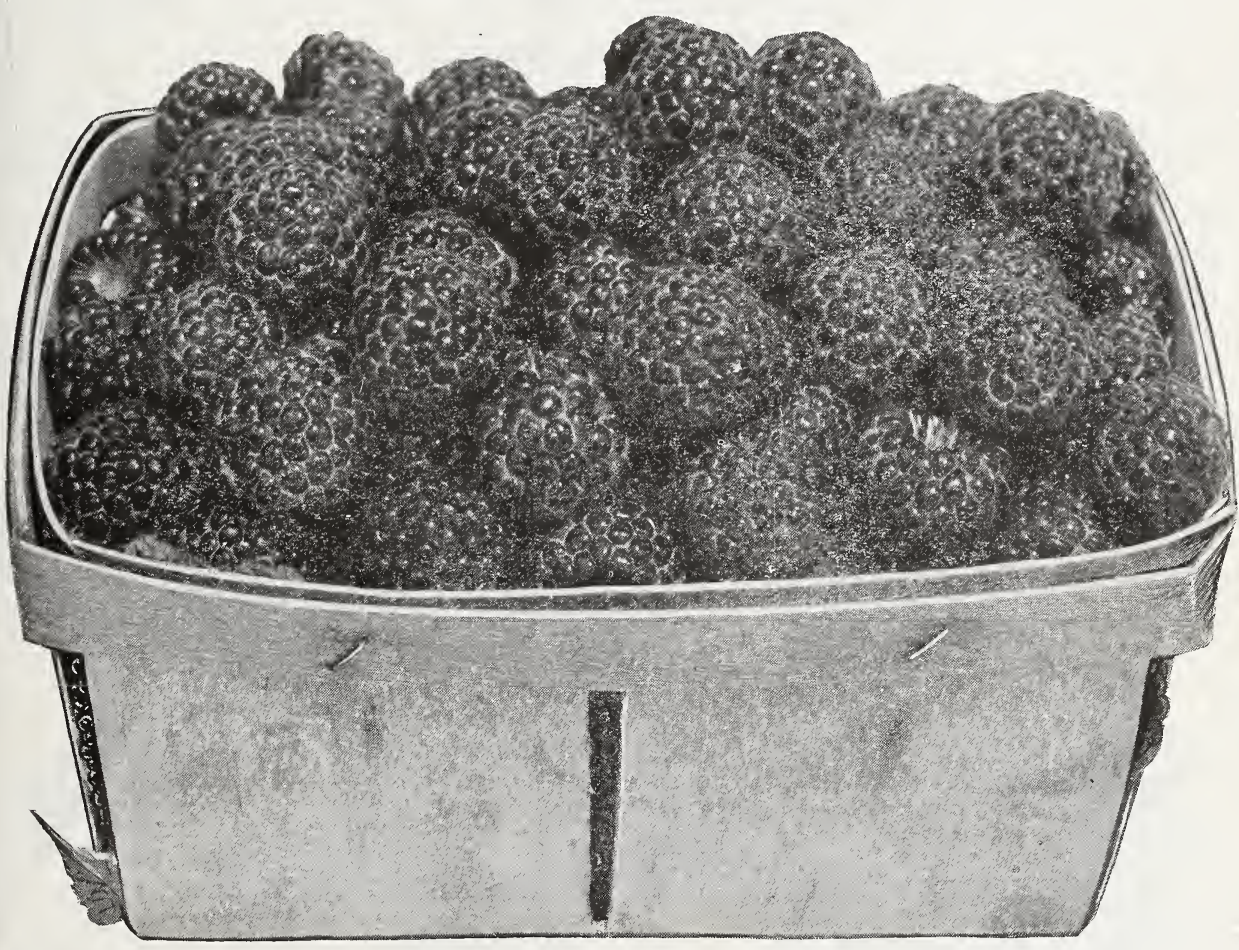

Kansas Raspberries

\section{Black Varieties}

CUMBERLAND-Largest black raspberry known; unusually strong grower, perfectly hardy. The most profitable raspberry grown.

GREGG-Extra big, enormously productive. Hardy; firm black meaty berries. Late ripening and firm for shipping.

KANSAS-Originated at Lawrence, Kan. Healthy, vigorous grower; early; berry is as large as Gregg and as good a shipper. Very productive, and valuable for early market.

OLDER-Originated in Iowa and has stood the severest winters well. Coal black, as large as Gregg and five days earlier. From its size, quality, hardiness and great productiveness it promises to head the list.

PALMER - A new early black cap variety; ripens its fruts just before the Gregg, but ripens it in shorter time. Good quality; vine is a strong grower and one of iron clad firmness.

\section{Yellow Varieties}

GOLDEN QUEEN-Large, beautiful translucent amber color and exceptionally firm; very productive. The canes are of the strongest growth and quite hardy.

\section{Loganberries}

Hybrid between a blackberry and a red rasp. berry, originated in California. Fruit as large as a blackberry, but of deep red color. Excellent as a novelty.

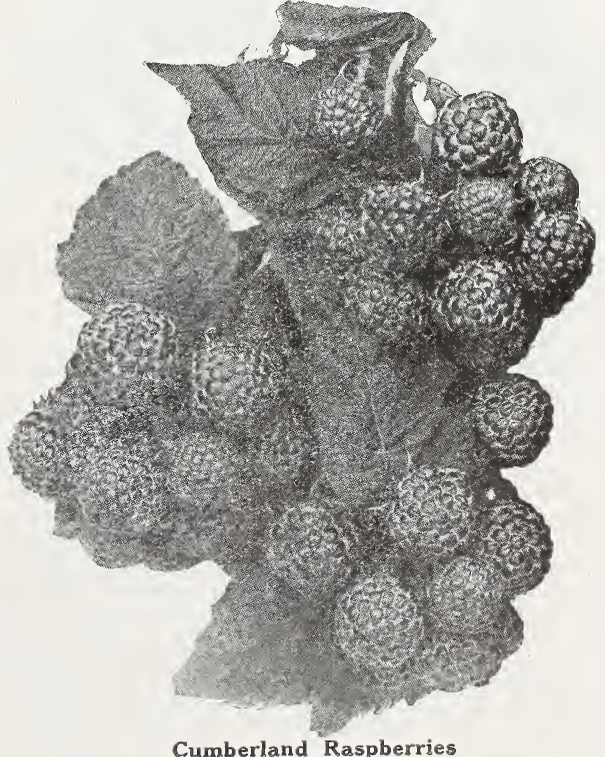




\section{Blackberries}

Plant four feet apart in rows six feet apart. Pinch the canes back when four feet high. Light, moderately rich land is preferable.

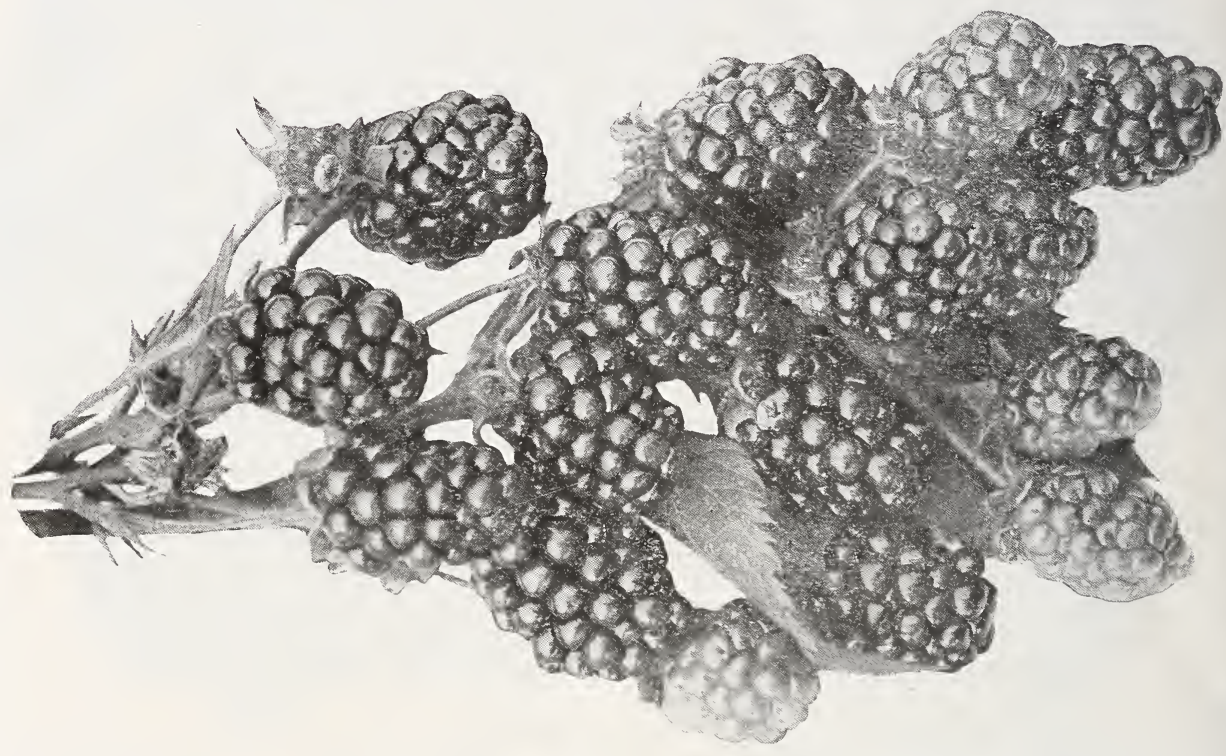

Snyder

ANCIENT BRITON - Very vigorous, healthy, hardy loaded with good-sized berries of fine quality. For sections subject to severe winters, Ancient Briton is first-class.

EARLY HARVEST - One of the earliest, but needs winter protection north. Medium size, quality good; prolific.

ELDORADO -A valuable blackberry for our northern climate. The berries are large, jet black, ripen well together and arc borne in large clusters; they are sweet and delicious, have no hard core, and keep well after picking.

MERSEREAU-Renowned for hardiness of cane, great productiveness and large size berry. Is not "seedy" like many other sorts. Fruit jet black, and does not change color. Berries rich, melting and luscious, with little or no core.

RATHBUN-This new blackberry has been tested over a wide area and is said to surpass any blackberry on the market. Berries large, jet black and of very fine quality. Ripens early.

SNYDER-The old standard. Very hardy, consequently much raised in cold climates. Berries medium size, juicy, rich; strong, stout cane, thrifty growth and a very broad leaf.

STONE'S HARDY-Is claimed to be even hardier than Snyder. It is a vigorous grower; berries glossy black and of a good flavor. About eight days later than sinyder and lasts two weeks.

TAYLOR - A good succession for Snyder in cold climates. Ripens its large, luscious berries some weeks later. Vigorous, hardy, fruitful.

\section{Dewberries}

LUCRETIA - Fruit very large, luscious and sweet; perfectly hardy, healthy, enormously productive; a very profitable market fruit; the vines should be allowed to remain on the ground during the winter and staked up early in the spring. Fruit ripens early, is often onc and one-half inches long.

\section{Strawberry-Raspberry}

A wonderful combination of strawberry and raspberry. Bush dies to the ground in the fall. Fruit red, in size and shape like a strawberry. Very delicious. Does well in most localities, a rather moist soil preferable. Splendid for jellies and jams.

\section{Dwarf Juneberry}

Fruit borne in clusters. Reddish purple, changing to bluish black. Excellent for canning. The fruit is eagerly devoured by birds, which leave the finest fruits untouched where this is plentiful. 


\section{Currants}

BLACK NAPLES-Very large, black, rich, tender and excellent for jellies and wine. Very productive.

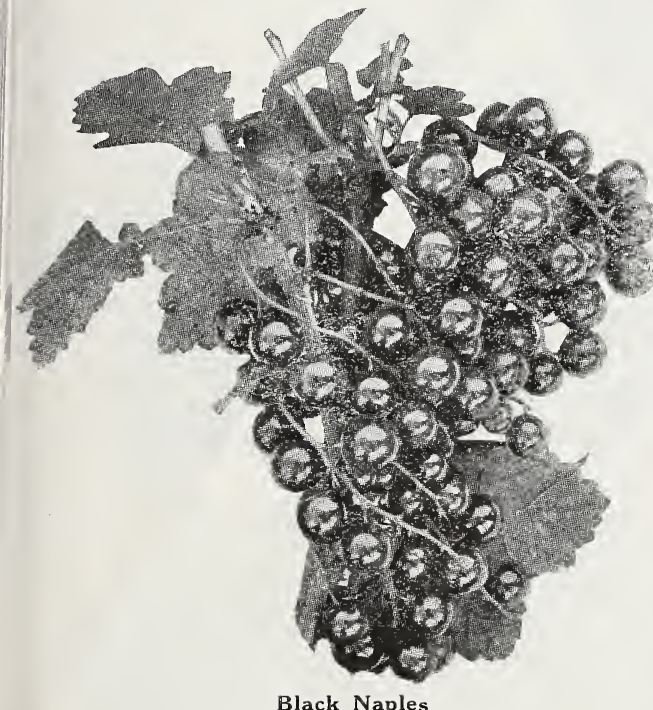

CHERRY - The largest of all red currants; berries sometimes more than one-half inch in diameter; bunches short; plant very vigorous and productive when grown on good soil and well cultivated.

FAY'S PROLIFIC-For size, beauty and productiveness it is a remarkable red currant. The berry is equal to cherry currant, while the Havor is superior. The stem is long, which permits rapid picking, valuable for both market and home. Fruit hangs on well, never dropping, as in other currants.

HOLLAND - A very strong grower; canes stout and capable of holding up the enormous crop it always bears. It is quite late, thus prolonging the season. Clusters long, berries very large.

NORTH STAR-New seedling; very vigorous; perfectly hardy; bunches long and well filled with fruit.

PER.FECTION-Bright red, and of a size larger than the Fay; size of berries is main. tained to end of bunch. It is one of the most productive Currants. Rich, mild, sub-acid flavor and having plenty of pulp with few seeds. You can pick Perfections fast as cherries.

POMONA-This is one of the most profitable currants for the market; while not the largest in size, it outyields all other varieties. Color is a beautiful bright red, berry sweet and less acid than most of the general varieties; good size, and larger than Victoria; a vigorous grower with healthy, hardy foliage.
RED DUTCH - Old, well-known sort of good quality; great bearer. Fine market variety. Vigorous and upright grower.

VICTOR.IA-Very large; bright red; bunches very long; late; very productive and valuable. This is a standard, good, and reliable currant.

WHITE DUTCH-White; medium size; vigorous grower and good bearer; bunches very compact; early. Fruit requires less sugar than some others; excellent for jellies.

WHITE GRAPE-Very large, yellowish white; sweet, or very mild acid; excellent for the table. The finest of the white sorts, very productive.

WILDER-Very large; bright red and attractive; a splendid sort; not so acid as most. Bush very productive; large bunches; ripens rather early, fruit keeps well.

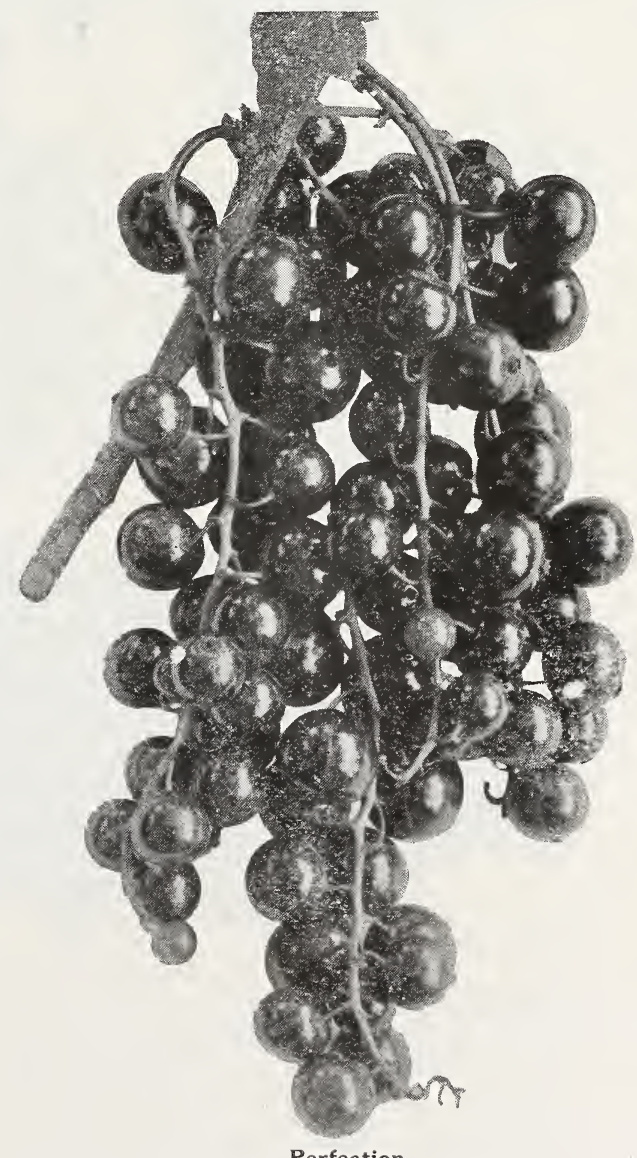

Perfection 


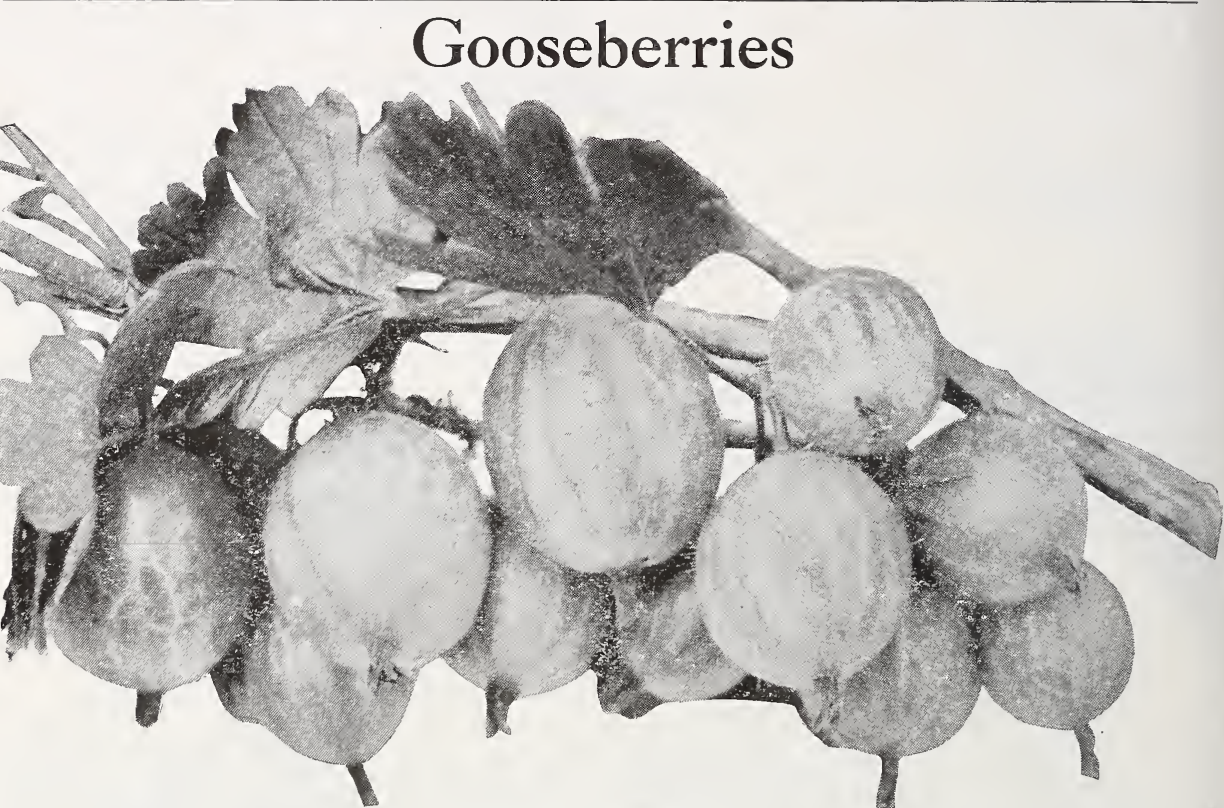

Downing Gooseberries

DOWNING - Fruit very large, flesh whitish green, soft, juicy and good; plant vigorous and prolific; one of the best.

HOUGHTON-The old, well-known sort; pale red, sweet and good. It is rather small, but a productive, healthy and very reliable gooseberry.

INDUSTRY-Very large; dark red, hairy, of delicious quality. In a cool, rich soil with a northern exposure it will yield an abundance of large, luscious fruit. Under favorable conditions its immense crops and exemption from mildew will repay the attention it requires. Not an ironclad. English sort.

JOSSELYN (RED JACKET)-Large size, smooth, prolific and hardy. Has been tested by the side of all leading varieties, is freest from mildew of all. A wonderful cropper, with large, smooth, pale red fruit of first class flavor.

PEARL - A cross between Houghton and one of the large English varieties. It is very hardy and entirely free from mildew; superior in size and quality; as productive as Downing.

\section{Strawberries-Everbearing Varieties}

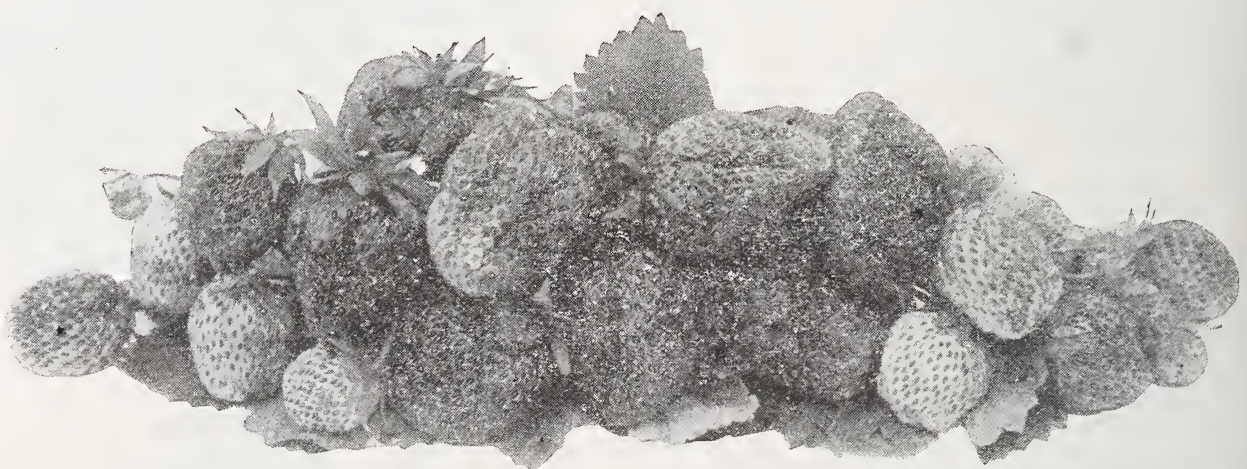

\section{Progressive Everbearing Strawberries}

AMERICUS EVERBEARING (P)-Large; firm; uniform shape; bright red through and through; has native wild strawberry flavor; very productive from May until hard freezing weather. Claimed by some to be the best of everbearing strawberries.

PROGRESSIVE EVERBEARING (P) - The berries are not as large as Superb and not so good quality, but they yield well and, we think, will be one of the best known varieties of fall bearers in a few years. Fruit of Progressive is of good size, smooth, of good color and appearance.

SUPERB EVERBEARING (P)-Very large, dark red and glossy; fine quality. It begins to bear in June with immense crops and continues until late in fall. It is one of the heaviest bearers of berries in June as well as a remarkable fall bearer. Will produce a fair crop of fruit the first summer. 


\section{Strawberries-Spring-bearing Varieties}

AROMA (P)-Large; dark red; uniformly roundish, heart shaped; flesh firm and of very good quality. Stands shipping well; plants vigorous and very productive; blossoms rich in pollen and is good fertilizer for imperfect varieties. Late.

BEDERWOOD (S)-This is one of the best standard varieties for market. It is early, a very strong yielder and continues a long time in bearing. A very strong staminate, the very best fertilizer for Warfield, Crescent or Haverland.

BRANDYWINE (S)-A fine, large, late, handsome, productive berry of excellent quality, regular conical form; dark glossy red, extending to the center.

BUBACH (P)-Very prolific, excellent flavor and largest size. A number of new varieties have been pitted against it, claiming superiority in one way or another, but Bubach is among the best, and continues to grow in favor.
SAMPLE (P)-One of the very best berries and seems to succeed nearly everywhere. Plants strong, large and healthy, producing in profusion large, dark colored berries of uniform size and color, firm enough to ship well. One of the standard sorts for both home and market.

SENATOR DUNLAP (S)-This berry is of the Warfield type, has a perfect blossom, is hardy, productive, a splendid keeper and able to hold its own under any "rough and tumble" methods of culture to which it is likely to be subjected. It is a very heavy bearer of good size, even fruit, of a very beautiful dark red color. It is a berry to grow for either home use or market.

WARFIELD (P)-There is probably no better or more profitable berry grown for market. It is in greater demand than any other berry for canning purposes, which also creates a good market for it. Care should be taken to use the right berries as fertilizers. It needs a strong pollenizer.

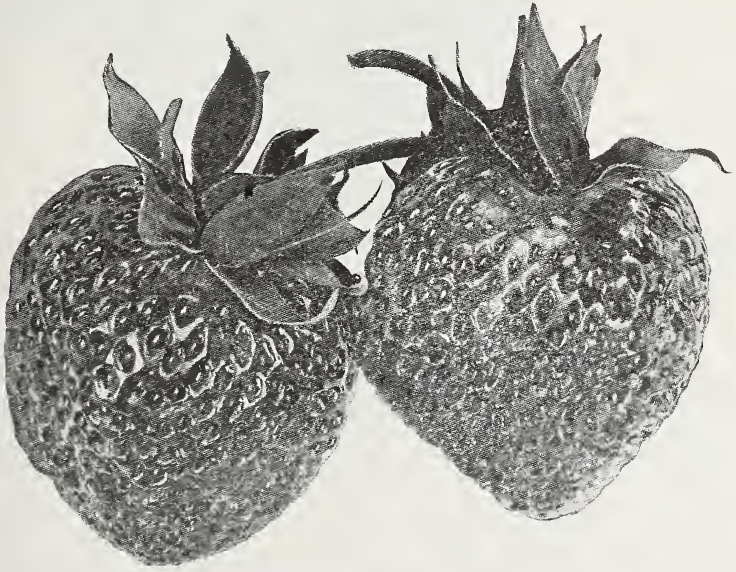

Senator Dunlap

HAVERLAND (P)-Profitable by reason of its productiveness and earliness; requires deep, heavy soil; plant exceedingly vigorous and healthy; fruit large, handsome and good, rather long in shape and of a bright, zlossy crimson; early.

GANDY (S)-Large, light crimson; flesh of firm, good quality. Plants vigorous but should be planted in swamp or moist, clay soils. Perfect. Late.

KLONDIKE (S)-Large; red; flesh firm, red to the core, with a mild and delicious flavor, unlike any other variety. Is very popular with southern growers who ship. Plant tall, compact, vigorous grower; resists frosts well and yields good crops. Perfect. Midseason.

ROUGH RIDER (S)-Perfect blossom, very productive, extremely vigorous, very large and attractive; one of the firmest, latest, best keepers, of finest flavor, sells at high prices. Berries very large, irregular in shape, dark colored. Promises to take its place as the very best late market variety.

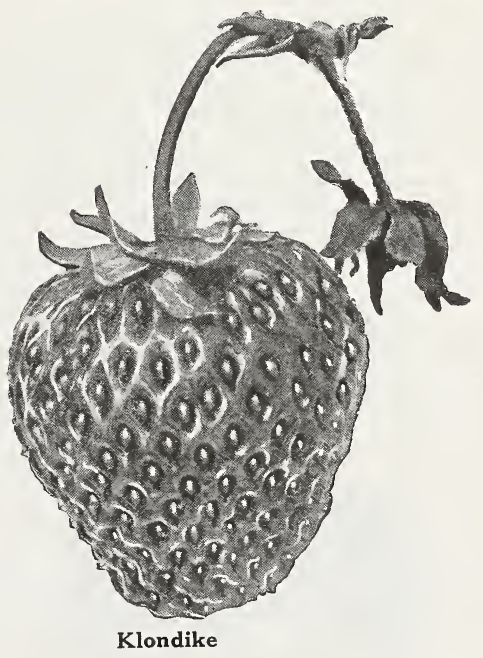

Rhubarb

This deserves to be ranked among the best early fruits in the garden. It affords the earliest material for pies and tarts, continues long in use, is valuable for canning. Use well grown roots, not divided old clumps.

LINNAEUS-Large, early, tender and fine.

VICTORIA-Very large, long stocks; a great market sort.

\section{Asparagus}

The first garden vegetable of spring; it is a great delicacy and comes in just when it is most needed. One hundred roots will supply a small family and will last for years. Set the plants about eighteen inches apart in the row. Spread the roots out in the bottom of the hole or furrow and gradually fill in as the plant grows, so that the roots will be about four inches deep.

CONOVER'S COLLOSAL-Best for general planting.

PALMETTO-Newer variety, earlier; probably as good. 


\section{Roses}

\section{Hybrid Perpetuals}

ALFRED COLOMB - Bright carmine red; clear color, large, deeply built form; exceedingly fine.

AMERICAN BEAUTY-The world-famous rose. Rich, rosy-crimson, exquisitely shaded. Magnificent buds. Flowers extra large and deep petaled; of beautiful form and very double. This hardy rose has the everblooming qualities of the Tea Roses with the delicious odor of the La France. The great American forcer and bedder, each shoot producing a bud. A universal favorite. Not hardy.

ANNE DE DIESBACH-Brilliant crimson, sometimes shaded with bright maroon. A superb garden sort; fragrant, one of the hardiest and best.

BARONNE DE BONSTETTIN-Rich, dark red, passing to velvety maroon; fragrant; very double.

CLIO-A rose of perfect form and finish, with broad, thick petals, high full center, beautiful from pointed bud to fully opened flower. The color is a delicate satiny blush with slightly deeper center. The plant is vigorous and blooms freely, displaying its great flowers on good stems against large rich leaves.

COQUETTE DES ALPS - White tinged witl pale rose, size medium, fine form, a free bloomer, dainty and attractive.

DUFFERIN-Rich, dark crimson, shading to maroon; large, full, fragrant; a good grower; one of the best dark roses.

FRAU KARL DRUSCHKI-Snow white, very large, perfect form. A vigorous grower and free bloomer. Bright, heavy foliage.

GENERAL JACQUEMINOT-This might be called the rose for the million, for it is still a universal favorite. Bright crimson-scarlet, exceedingly rich and velvety.

GENERAL WASHINGTON-Color brilliant crimson; very ricl and beautiful; large perfectly double and a free bloomer.

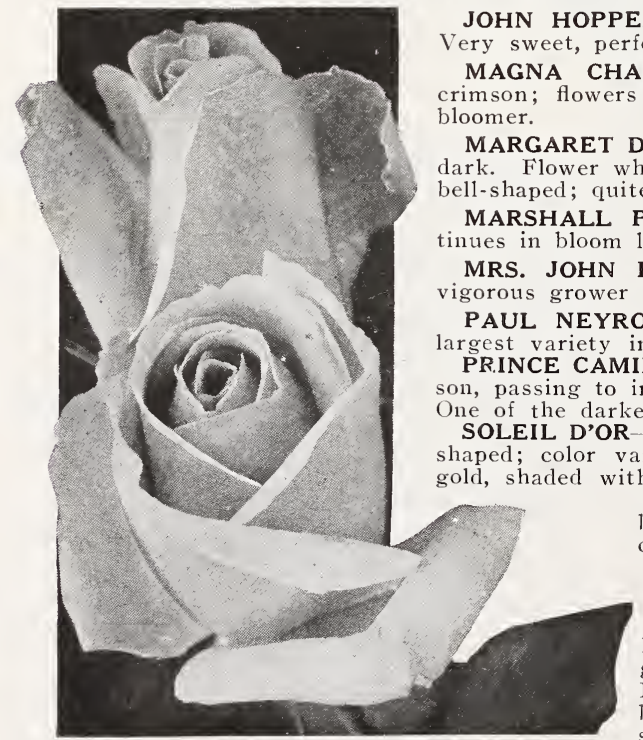

MAGNA CHARTA Bright, clear pink, flushed with violet crimson; flowers large, fine form, sweet, very double and free

MARGARET DICKSON-A very free grower, foliage large and dark. Flower white, with pale flesh center; petals are thick and (lon after others are and hardy. One of the most profuse bloomers. in cultivation; one of the best. ne of the darkest roses and very handsome.

D'OR-Large, full and globular, fragrant; buds conical shaped; color varying from gold and orange yellow to reddish gold, shaded with nasturtium red.

ULRICH BRUNNER-An upright grower with bright, healthy foliage. Flowers are a bright cherry red, good size and of fine form.

\section{Tree Roses}

These plants are very attractive with the long branches drooping and trailing to the ground, covered with great clusters of flowers. Flowers are semi-double, but are extremely beautiful on account of their abundance and showy colors. Not hardy. Best to plant in Frau Karl Druschki half barrel and give winter protection. 


\section{Climbing Roses}

CRIMSON RAMBLER-Nothing equals this as an all round hardy garden rose, on account of its brilliant color, profusion of bloom and length of time the flowers last. It may be used as a climber, or cán be grown in large bush form. It blooms in large clusters of 50 to 100 flowers in a cluster, covering the foliage its entire length with a solid mass of the most beautiful, perfectly shaped, miniature crimson blossoms. Blooms last of June and remains in flower longer than any other hardy out-door rose.

DOROTHY PERKINS - This is a splendid new shell-pink climbing rose. This new rose is of the same strong habit of growth as the Crimson Rambler, and the flowers are borne in clusters of thirty and forty and sometimes fifty to sixty. The flowers are large for a rose of this class. Very double and sweetly scented.

QUEEN OF THE PRAIRIE-Bright rose in clusters, vigorous, very free bloomer.

SEVEN SISTER.S-Fine, free bloomer, bright scarlet; claimed by some to be hardier than Prairie Queen.

\section{Hybrid Tea}

GRUSS AN TEPLITZ - Unquestionably the finest brilliant red, hardy, ever-blooming garden rose. The flowers are very showy and handsome. It blooms constantly and continues covered with flowers the whole season.

\section{Miscellaneous Hardy Roses}

HARRISON'S YELLOW-This variety blooms early, making a brave show with its bright yellow flowers. It has small faintly fragrant leaves and very thorny stems. In this variety the flowers are of medium size, semi-double, rich golden yellow, and produce very freely.

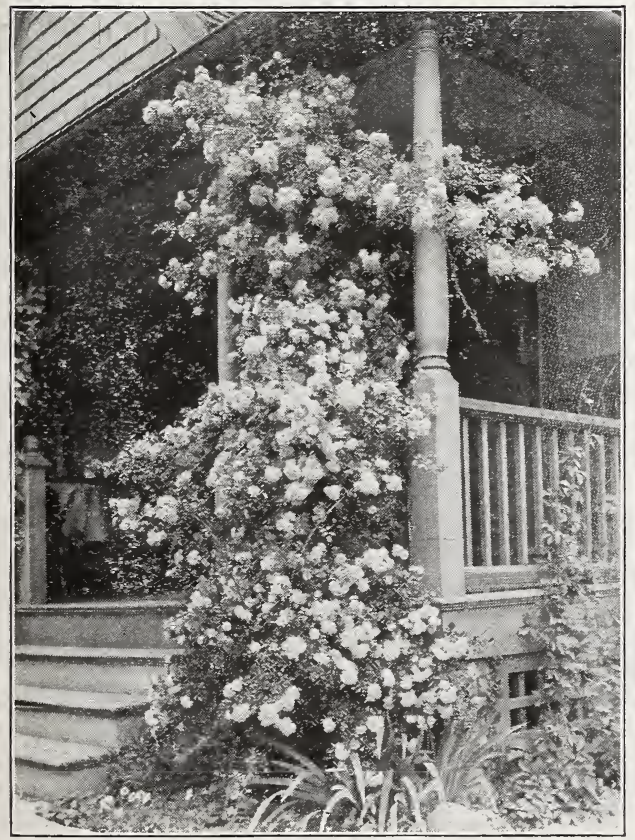

Crimson Rambler

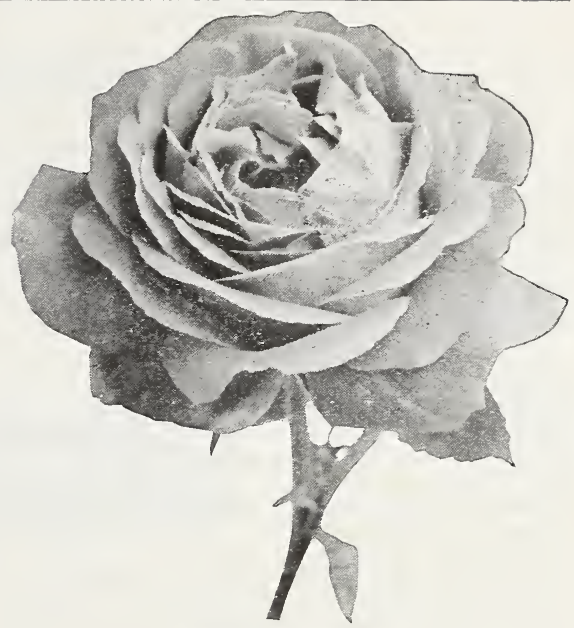

Gruss An Teplitz

PERSIAN YELLOW-Similar to above, but with flowers fuller and of better form. Bright yellow; the most double of this class. The finest hardy yellow rose.

MADAM PLANTIER-Flowers pure white of medium size; full; somewhat rosy in the bud form; produced in greatest abundance quite early in the season. The leaves are small; the bush hardy and spreading. Fine for masses, hedges, borders, cemeteries, etc.

CENTIFolia, Common or Cabbage Provence-Free. Rose color; large size, globular form; very fragrant. A superb variety.

\section{Baby Rambler Roses}

PINK BABY RAMBLER - A brilliant rose color.

RED BABY RAMBLER-Crimson flowers, Very attractive and nopular.

WHITE BABY R.AMBLER-Pure white flowers, produced in large candelabra-sliaped trusses.

\section{Moss Roses}

ADMIRAL DEWEY-Dark red, very vigor ous, one of the best.

BLANCH MOREAU-Pure white, large and full, perfect form and well furnished with dcep green moss. Very strong grower.

CR.ESTED MOSS-The deep pink buds are surrounded with a mossy fringe and crest; fragrant. One of the best.

CAPTAIN JOHN INGRAM-Dark velvety purple, large size, double.

GLORY OF MOSSES-Flowers large; color pale rose. A strong grower, with fine, healthy foliage.

PERPETUAL WHITE-Pure white, blooms in clusters, double, beautiful, vigorous.

SALET-Clear rose color, very double, of vigorous growth and abundant bloom. Perpetual. 


\section{Ornamental Shrubs}

The planting of ornamental shrubs is very largely on the increase, and this is as it should be, for with a good selection the lawn can always be beautiful. They are mostly of medium size, enabling one to plant a great variety on a small plat, and the wonderful assortment of foliage from the darkest green and purple to light orange and silver tints. This addition to the great variety in the blossoms, all unite to keep up a never failing interest. We have selected the very best for our climate.

F L O W E R I N G SHRUBS-Variegated or Colored Foliage - Barberry, Golden Elder. S y ring a Variegated, Weigela.

Shrubs that Flower in May-Flowering $\mathrm{Al}$ monds, Honeysuckle, Japan Quince, Lilac, Snowballs, Spireas, Wistaria, Spirea Van Houttei

In June Clematis, Deutzia, Elder, Honey suckle, Paeonies, Lilacs, Snowball, Spireas, Syringa, Weigela, Wistaria.

In July-Clematis, Spirea, Honeysuckle.

In August and September-Bignonia, Clematis, Honeysuckle, Hydrangea.

ALTHEA, or ROSE OF SHARON-Valuable because they bloom so profusely in late summer when other flowers are scarce. They form beautiful groups of hedges, their varietv of colors making it possible to use quantities of them even in small grounds.

ACACIA ROSE-This is one of the finest old shrubs in cultivation, perfectly hardy and an absolute blaze of beauty when in bloom.

ALMOND, FLOWERING -Pink and white varieties. These beautiful shrubs are desirable and scarce. Hardy.

CALYCANTHUS (Carolina Allspice)-A well known native bush bearing very double, purple fragrant flowers.

DEUTZIA-A very desirable shrub, of strong, nardy growth, bearing an abundance of beautiful racemes of double, pure white flowers.

ELDER GOLDEN-The leaves are a bright and constant golden color; the flower cluster pure white. Valuable for contrasts and for massing.
FLOWERING CRAB, BECHTEL'S-About the middle of May the trees are covered with beautiful, double, pink, sweet-scented flowers, that look like small roses at a distance. Tree is a moderate grower, hardy and of upright habit. One of the very best.

HONEYSUCKLE, UPRIGHT-White and pink flowers which contrast beautifully with the foliage. Blossoms in June.

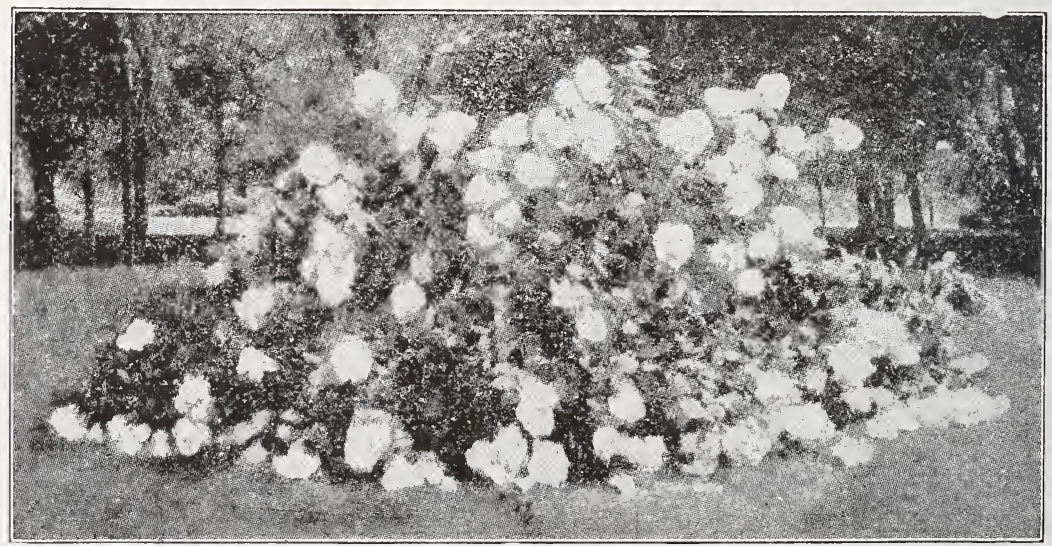

Hydrangea 
HYDRANGEA PANICULATA GRANDIFLORA - These plants are absolutely hardy, grow in any soil and bloom the same year they are set out. They flower abundantly, bearing hundreds of immense panicles of bloom. White turning to rose in autumn. An annual shortening of branches tends to increase the size of the flowers. Very fine and valuable for cemetery planting.

LILAC (Common Purple) Bluish purple flowers, well known.

LILAC (Common White)-Cream white flowers.

LILAC (Persian Purple) - Of more slender growth and finer foliage than the common lilac. Flowers purple in large, loose panicles.

SNOWBALL (Common)-A popular shrub, Makes a large bush. Bears balls of pure white flowers in June.

SPIREAS-Decidedly the best and hardiest family of shrubs for the Northwest. Many beau- tiful varictics of differcnt colors and times of flowering, from May to September. Of easiest culture; should be planted everywhere.

S. AUREA-Golden leaf Spirea, with white blooms and golden foliage; very showy.

S. BILLIARDII-Blooms in beautíful rose-colored spikes from early summer till frost. Hardy and very desirable.

S. VAN HOUTTEI-Graceful, with long, drooping sprays, thickly studded with handsome, pure white flowers; hence its popular name, "Bridal Wreath." The finest Spirea of them all.

S. CALLOSA ROSEA-Flowers from June to September; of a pretty dwarfish habit; bloom rose color.

SYRINGA (Mock Orange)-Beautiful, tall, vigorous, hardy, with profuse, white, orangelike flowers in May. Very popular.

WEIGELA ROSEA-Hardy, with profuse, rosy, trumpet shaped flowers in May. The most superb shrub of the season.

\section{Hardy Climbing Vines}

Ornamentals of this class are so hardy and so beautiful that they deserve greater attention than they receive. No artist can produce pictures equal to the wealth of beauty displayed by the elegant Wistaria, the graceful Honeysuckle, or the charming and magnificent Clematis when in the glory of full bloom.

\begin{abstract}
AMPELOPSIS (American Ivy or Virginia Creeper, also called Woodbine)-A very rapid grower, having beautiful dark green foliage, assumes rich crimson hues in autumn.

AMPELOPSIS (Veitchii or Boston Ivy)Leaves a little smaller and more ivy like in form than the foregoing. Overlapping each other they form a dense sheet of green. The plant requires a little protection the first winter until it is established.
\end{abstract}

C. MADAME EDOUARD ANDRE-Flowers large, of a beautiful bright velvety red, very free flowering and continuous bloomer.
BIGNONIA (Scarlet Trumpet Flower)-A splendid climber, vigorous and hardy, with clusters of large, trumpet-shaped, scarlet flowers in August.

CLEMATIS-The different varicties and species of Clematis now in cultivation are of the highest beauty and utility. They vary greatly in their foliage and flowers and are adapted to various uses.

C. COCCINEA-Distinct from other varieties; bright coral scarlet flowers. July to October.

C. FLAMMULA-The flowers of this variety are very fragrant; requires a slight protection in winter; very desirable.

C. JACKMANII-A very profuse blooming variety with flowers from four to six inches in diameter, of an intense violet-purple color borne successionally in continuous masses on the summer shoots. The very best sort for general planting.

C. HENRYII-Fine bloomer; flowers large, of a beautiful creamy white, consisting generally of from six to eight sepals. June to October.

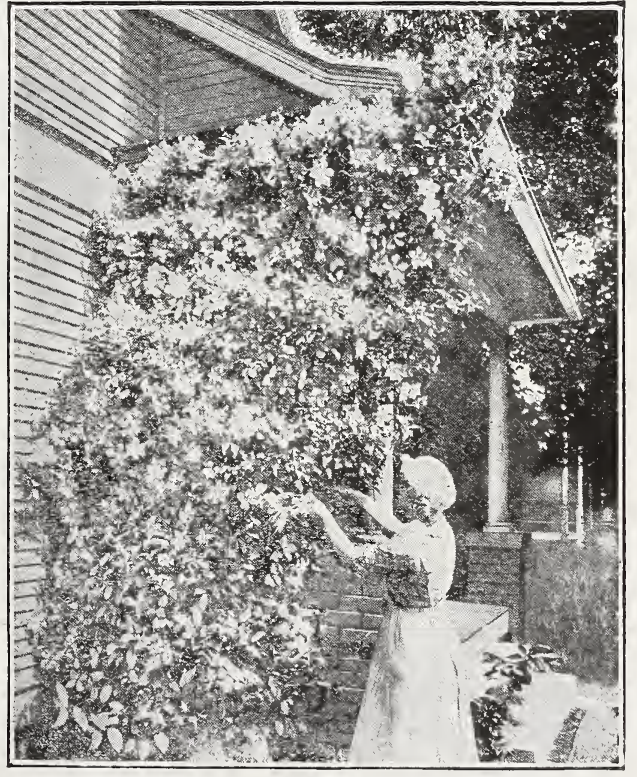

Clematis 


\section{Hardy Climbing Vines-Continued}

C. PANICULATA - A great novelty. One of the most desirable, useful and beautiful of hardy garden vines, a luxuriant grower, profuse bloomer with fine foliage. Flowers of medium size, very pretty and fragrant, produced in the greatest profusion in late summer.

HONEYSUCKLE (Monthly Fragrant)-Blooms all summer; very sweet.

HONEYSUCKLE (Hall's Japan)-A strong, vigorous, evergreen variety with pure white flowers changing to yellow. Very fragrant; covered with flowers from June to November. Better have some winter protection.

WISTARIA - A most beautiful climber of rapid growth, producing long, pendulous clusters of pale blue flowers. When well established makes an enormous growth. It is very hardy and one of the most superb vines ever intro-

\section{Hardy Herbaceous Perennials}

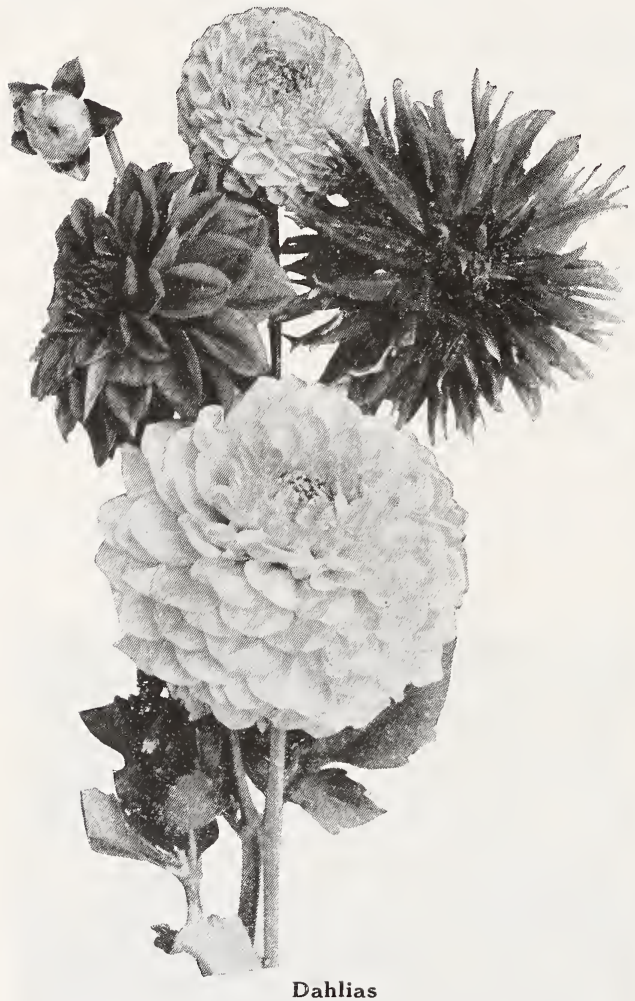

DAHLIAS - Well known autumn flowering plants, growing from two to five feet high, and producing a profusion of flowers of the most perfect and beautiful form, varying in color from the purest white to the darkest maroon.

GLADIOLI-Of all our summer flowering bulbs gladioli stand at the head of the most varied and beautiful class. The flowers are produced in spikes two feet in height and upwards; the brilliant scarlet and crimson of some form a striking contrast with the delicate shades and penciling of the lighter colored varieties. By planting at intervals from May 1st to middle of June a succession of flowers can be had from July to October.

GOLDEN GLOW-We call attention to this notable novelty, and offer it as the finest herbaceous border plant introduced for many years. It is of easy growth and is giving complete satisfaction. But few plants can vie with it in attractiveness.
There is no floral novelty hefore the public to be compared to it for effectiveness and worth.

PEONIES-Herbaceous Peonies are among the showiest and most useful of hardy plants, and are fast becoming popular with the public They are all hardy and admirably adapted to the climate of our most northern states, growing well in almost any location or soil, although the flowers will be finer and the colors brighter. if planted in a deep, rich loam, well manured. The flowers are in all shades, from red and lilac to white, with blooms from four to eight inches in diameter. Many of them are very double and have a delicate and refreshing fragrance.

YUCCA FILAMENTOSA (Adam's Needle)Thread-leaved, creamy white; stem three to four feet high, covered with bell-shaped flower, on laterals forming a pyramid; very striking.

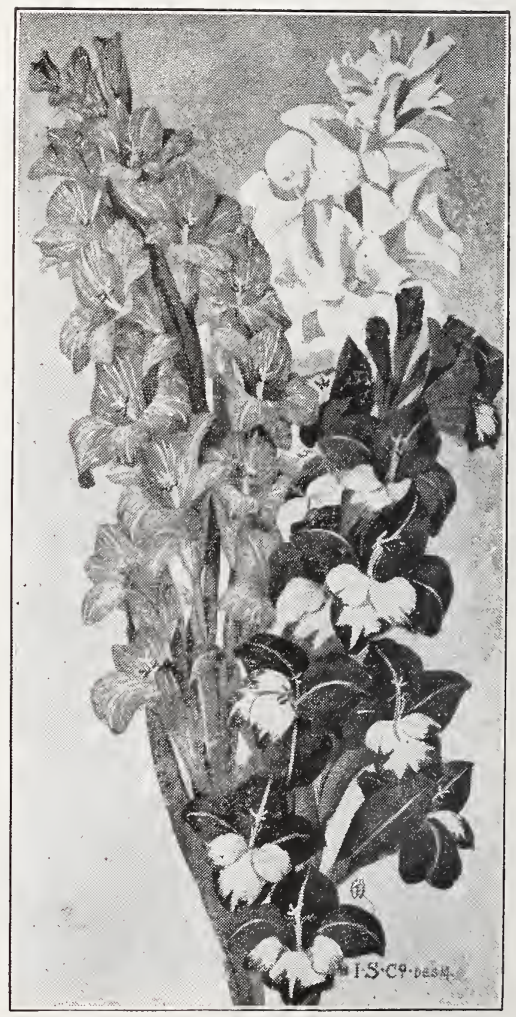

Gladioli 


\section{Flowering Bulbs}

\section{to be Planted in the Fall} ble.

CROCUS-In various colors, single and dou-

HYACINTHS-Among the bulbs used for winter flowers, Hyacinth stands foremost on the list. Two methods are employed in flowering the hyacinth in winter, one in glasses filled with water, the other in pots or boxes of soil.

JONQUILS-Pretty varieties of the Narcissus, have a very agreeable fragrance; adapted to either pots or out-door culture. The bulbs being small six or eight may be put in a sixinch pot.

LILIES-The lilies are entirely hardy with few exceptions. Quite fragrant and most of the varieties are very beautiful. pan.

LILIUM AURATUM-Gold banded lily of Ja-

L. CANUIDUM - Common white.

L. HARRISII (Bermuda Easter Lily)-Pure white, trumpet shaped flowers, very fragrant. The finest lily grown.

L. LANCIFOLUM ROSEUM (Rose Spotted).

L. LANCIFOLIUM RUBRUM (Red Spotted).

L. TIGRINUM (Double Tiger Lily)-Bright orange scarlet with dark spots.

LILY OF THE VALLEY-This lily is as hardy as any plant can possibly be, and when planted in open ground will increase pretty rapidly.

TULIPS-Owing to the late spring frosts, bedding plants cannot safely be planted before the early spring flowering bulbs are through blooming. They thrive well in almost any soil. Should be planted during October and November.

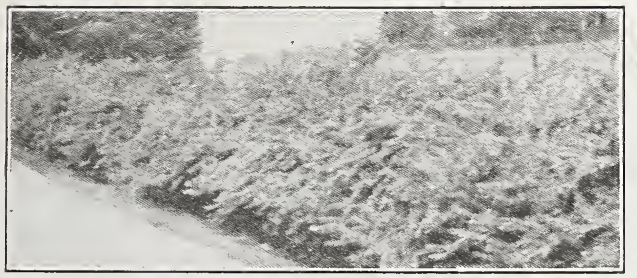

Barberry (Purple Leaf)

\section{Hedge}

BARBERRY (Purple Leaf)-An interesting and beautiful variety with violet purple leaves and red fruit.

JAPAN QUINCE-Unquestionably a fine plant for an ornamental hedge. Grows very compact; will submit to any amount of pruning, while the brilliant and showy scarlet flowers make it exceedingly attractive.

PRIVET (Amoor River or Russian)-This is the most beautiful hedge plant grown. It has a luxuriant, glossy leafage and thick clusters of fragrant white flowers. Hardy, free-growing, of dense, neat habit; attractive all the year, in

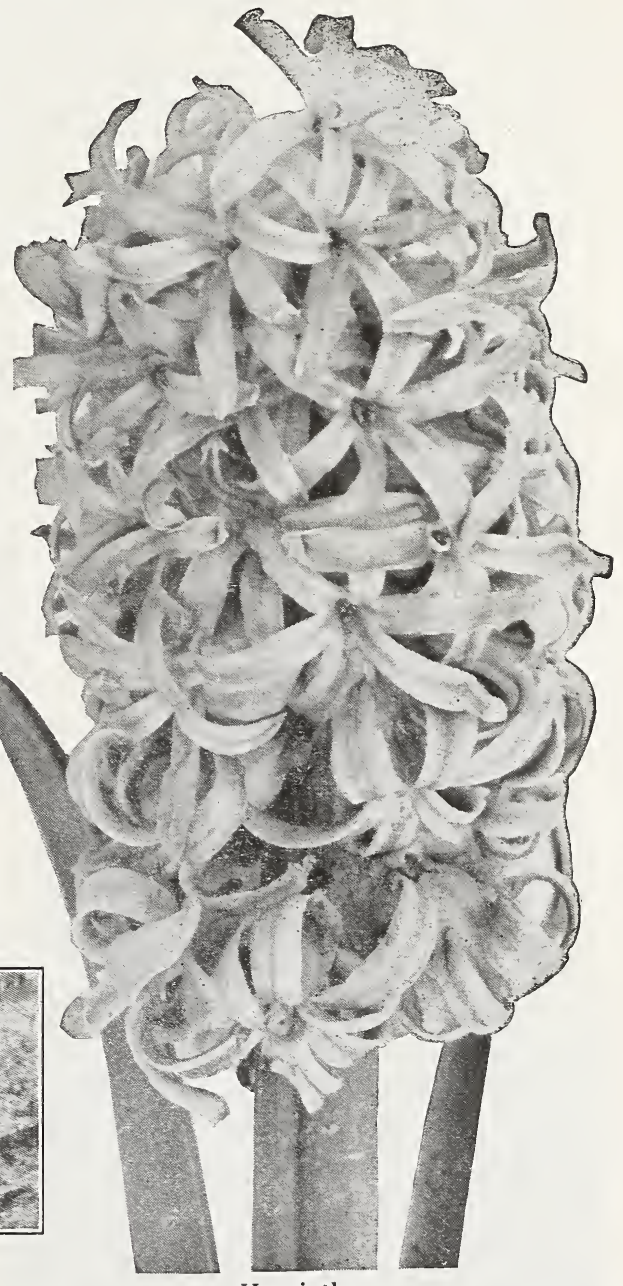

Hyacinths

\section{Plants}

berry, leaf, or flower. Makes a beautiful speciinen plant, a fine screen, group or hedge.

PRIVET (California)-One of the finest for hedges where it does not winter-kill. The foliage is large and glossy, and is almost evergreen. While we can furnish the California Privet for hedging purposes, we do not recommend it as being absolutely hardy north of the 41st parallel of latitude.

OSAGE ORANGE - One of the very best for defensive hedges where it can be grown without winterkilling. It is of vigorous habit, and rapid, dense growth, and when kept properly trimmed it not only makes an effective hedge, but it is decidedly ornamental. 


\section{Hardy Ornamental Trees}

The stock of ornamental trees that we offer will be found to comprise a suffirient number of kinds that are really valuable, so that our customers may, from the list offered, secure such a variety as will give full satisfaction.

For Streets, Roads and Wide Avenues-American Elm, Sugar and Silver Maple, Carolina Poplar.

For Driveways through Lawns and Parks-Norway Maple, Tulip Tree, Catalpa, American Linden.

Single Specimens of Large Growth to be Branched from the Ground-Birches, particularly CutLeaf Weeping; Austrian and Scotch Pines, Norway and Colorado Spruces, Balsam Fir.

Single Specimens of Medium Growth to be Branched from the Ground--Prunus Pisardii, Hemlocks, White Pine, Arbor Vitae.

Strong Growing Trees of Pyramidal Habit-Carolina Poplar, Balsam Fire, Pyramidalis Arbor Vitae.

Trees that Thrive in Moist Locations-American Elm, American Linden, Ash, Catalpas, Poplars and Willows.

Trees that Thrive on Dry Knolls or Poor Soils Silver Leaf Maples and Poplars.

Best Trees for Windbreaks-Norway and White Spruces, Scotch and White Pine, Carolina Poplars and Silver Maples.

Flowering Trees-Judas Tree, Fringe Tree, White and Purple Lindens, Horse Chestnut, Catalpas .

Cut-Leaved Trees-Cut-Leaf Weeping Birch, Weirs Cut-Leaf Maple.

Purple and Scarlet-Leaved Trees-Purple-Leaf Beech, Plum, Purple Norway Maple.

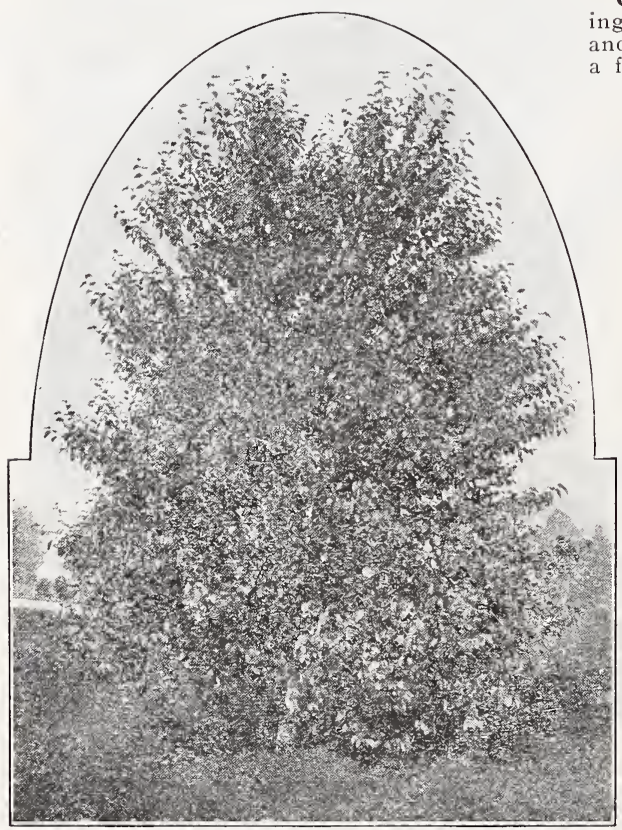

Birch, White

ASH, WHITE-Rapid growing tree, of fine, sym. metrical outline. A valuable street or park tree and should be extensively planted.

BIRCH, WHITE-A beautiful native tree, particularly in the northern part of the country. Its shining white bark and slender, dark brown branches make it a conspicuous and very attractive object. Foliage large and handsome.

BOX ELDER-A fine, rapid growing tree, with handsome, light green, pinated foliage and spreading head; very hardy.
CATALPA-A native of the South. A rapid growing, beautiful tree, with large heart-shaped leaves and pyramidal clusters of white and purple flowers foot long. Blooms late in July.

CHESTNUT, AMERICAN or SWEET-Well known beautiful tree, valuable for fruit and timber. Should be planted only on thin, dry soils.

CHESTNUT, HORSE-Common or white, flowering. A very beautiful, well known tree, with round, dense head, dark green foliage, and an abundance of showy flowers in early spring.

ELM, AMERICAN WHITE-The noble, spreading, drooping tree of our woods. One of the grandest of park or shade trees.

FRINGE, PURPLE-Very conspicuous in mid-summer when veiled with a thick mist of dusky purple flowers, so light as to simulate wreaths of smoke. This is sometimes called "Smoke Tree."

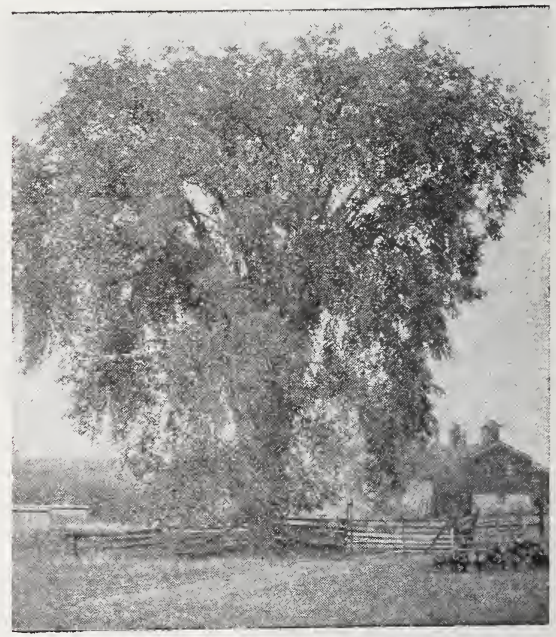

Elm, American White 


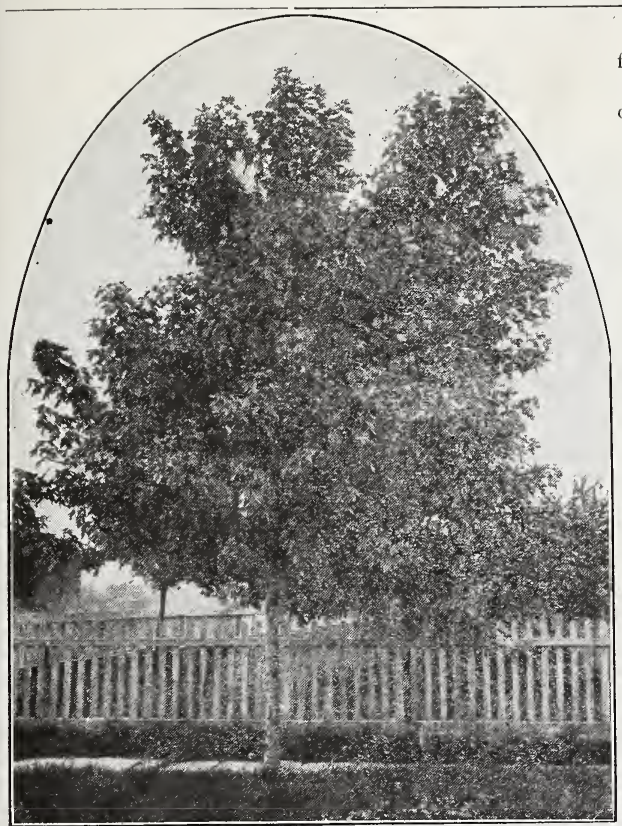

SUGAR MAPLE-A beautiful, stately tree of fine form; a desirable shade tree. Slow grower.

PLUM (Prunus Pissardii)-Purple leaved. One of the most beautiful purple leaved trees or shrubs. The leaves and shoots are of a rich, peculiarly vivid dark purple, holding the color well through the entire season. It also pro. duces small, white, single flowers in great profusion in May, followed by black fruit of ornamental appearance. Winter pruning gives stronger shoots and larger leaves.

WALNUT, BLACK-Valuable for nuts and timber. It is hardy and succeeds best on a rich, deep, moist soil. Too well known for long description.

\section{Weeping Varieties}

BIRCH (Cut-Leaf Weeping)-Erect, stately, rapid growing tree, with long, slender, pendant branches, delicately cut leaves and silvery white trunk; especially fine when near ever. greens; hardy; the most elegant weeping tree on the list.

ELM CAMPERDOWN, WEEPING -A vigorous grower; leaves large, dark green and glossy, covering the tree with a luxuriant mass of verdure; very desirable as an ormamental.

\section{Maple (Silver Leaved)}

CAROLINA POPLAR - Takes front rank among best of poplars; it is one of the most rapid growers among shade trees. Its branches spread just enough to give it a symmetrical appearance. It has advantages over other shade trees because it will grow on any kind of soil, swampy or muck, light or heavy. Its roots penetrate the hardest soil, it withstands all hardships and thrives in places where others fail to live. It is easily started and gives shade in a short time. Its leaves are large and stay green till quite late in the fall.

CRAB (Bechtel's Double Flowering)-This blooms in early spring exhaling a most delightful fragrance from its masses of double, delicate pink flowers.

ELEGANUS ("Russian Wild Olive") - A very hardy and quite a rapid growing tree with a silvery foliage; very striking in appearance. Its ability to endure extreme cold and drouth makes it desirable for ornamental lawns and for hedges.

FRINGE, WHITE-A beautiful little tree, with large, soft, heavy leaves, almost hidden in spring time by clouds of delicate, fragrant, white flowers of a drooping, fringe-like character.

LINDEN (American or Lime)-A rapid growing, large, beautiful native tree. Flowers very fragrant.

MAPLE (Silver Leaved) - Leaves white underneath; of rapid growth; very ornamental and one of the best street trees we have.

MAIDEN HAIR or GINKO TREE-One of the most beautiful lawn trees. Beautiful, rich, glussy, fern-like foliage. Rapid growth. A tall, upright grower.

MOUNTAIN ASH-Very hardy and handsome with fine clusters of scarlet berries hanging on the trees in winter; a beautiful tree for the lawn.

NORWAY MAPLE - Of spreading, rounded form; foliage large, dark green; a rich and majestic shade tree.

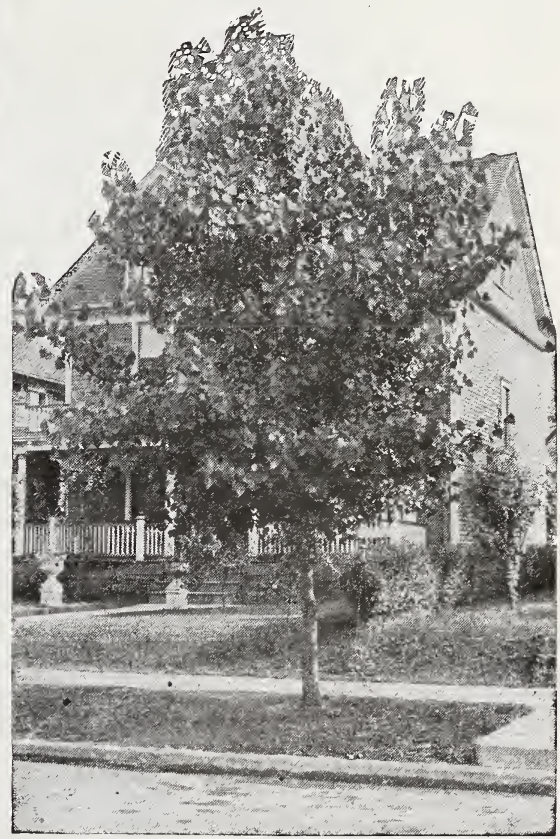

\section{Carolina Poplar}

MOUNTAIN ASH (Eurozean Weeping)-A strong grower; remarkably pendant; perfectly hardy; succeeds admirably on prairie soil.

TEAS' WEEPING MULBERRY-Fiorms a perfect umbrella shaped head, with long slender branches drooping to the ground, parallel to the stem; very hardy; one of the prettiest small weeping trees.

WILLOW (Kilmarnock Weeping)-One of the very finest weepers, but the stock upon which it is usually budded is not perfectly hardy in exposed situations. 


\section{Hardy Evergreens}

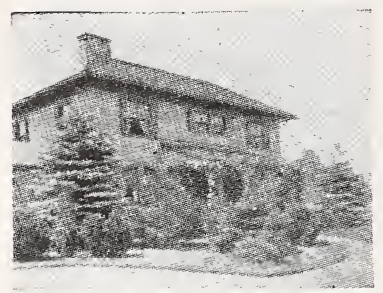

Evergreen Planting

In handling and planting evergreens never allow the roots to become dry for an instant. Their juices are resinous, and when once dry, water has no power to restore them; dip the roots in "grout" or very thin mud, and plant quickly; cover the roots with fresh soil and with a heavy piece of wood beat the earth solid over them. Fill up and pound

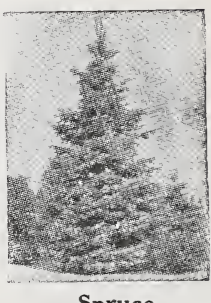

Spruce again, and finish by bringing fresh loose earth about the tree with a hoe. No wind can now bend the trees about so as to break the tender rootlets as fast as formed.

U'se Scotch Pine, White Spruce, Norway Spruce, and White Pine for high screens, and Arbor Vitae or Red Cedar for low ones.

ARBOR VITAE (American)-This plant is, all things considered, the finest evergreen for hedges. It is very hardy and easily transplanted, few plants failing if properly handled. It grows rapidly and with little care, or rather by easy management, it soon forms a most beautiful hedge, very dense and perfectly impervious to the sight. It is never planted to turn stock, but it forms a most desirable and ornamental screen to divide the lawn from other grounds.

ARBOR VITAE (Pyramidalis)--A superb, new and hardy sort, of very compact habit; much better than the Irish Juniper, and grown in a perfect column. Largely planted in cemeteries, owing to the small amount of space it occupies. This is perhaps the most valuable Arbor Vitae in cultivation.

\section{BALSAM FIR-A} handsome, compact, erect, pointed tree, with short, sof $t$ leaves, which are dark green above, silvery beneath, good grower.

\section{HEMLOCK - An} elegant, pyramidal tree, with drooping branches and delicate dark foliage, like that of the Yew; distinct from all other trees. It is a beautiful lawn tree and makes a highly ornamental hedge.

IRISH JUNIPER - Very erect and tapering in its growth, forming a column of deep green foliage; a pretty little tree or shrub, and a general favorite for its beauty and hardihood.

P.I N E, A USTR. I A N or BLACK-A remarkably robust, hardy, spreading tree; leaves long, stiff, dark green; growth rapid; valuable for this country.
PINE, SCOTCH-Is one of the most rapid growers while young, one of the best for shelter planting in the West. It will make the best windbreak in the least time of any; it is a very valuable species.

PINE, WHITE-One of the best evergreens. The foliage is a warm, light green, often with a bluish tinge. The leaves, in fives, are three or four inches long, soft and delicately fragrant. It does not grow as rapidly the first few years as some, but after being planted eight or ten years it is the most rapid grower of all our evergreens.

RED CEDAR-A well known tree with fine deep green foliage; variable in its growth; suitable for ornamental hedges.

SPRUCE, COLORADO BLUE -This species has been tested at various points on the prairies of the West and Northwest with perfect success, and during a temperature of 30 degrees below zero, in exposed situations, entirely uninjured. One of the hardiest evergreens and the most beautiful in color and outline. "This is the king of spruces, clothed in royal robes of silver and sapphire, a very Kohinoor among the gems of the Rockies."

SPRUCE, NORWAY - A lofty, elegant tree of perfect pyramidal habit, exceedingly picturesque and beautiful. One of the best evergreens for windbreaks.

Spruce, Colorado Blue

SPRUCE, WHITE-A tall tree with compact branches and light green foliage. Very handsome.

Our evergreens are given special care, handled carefully and transplanted frequently, so there is no danger in moving them from our nurseries. Each tree is planted so that it grows symmetrically and develops into a shapely specimen. 


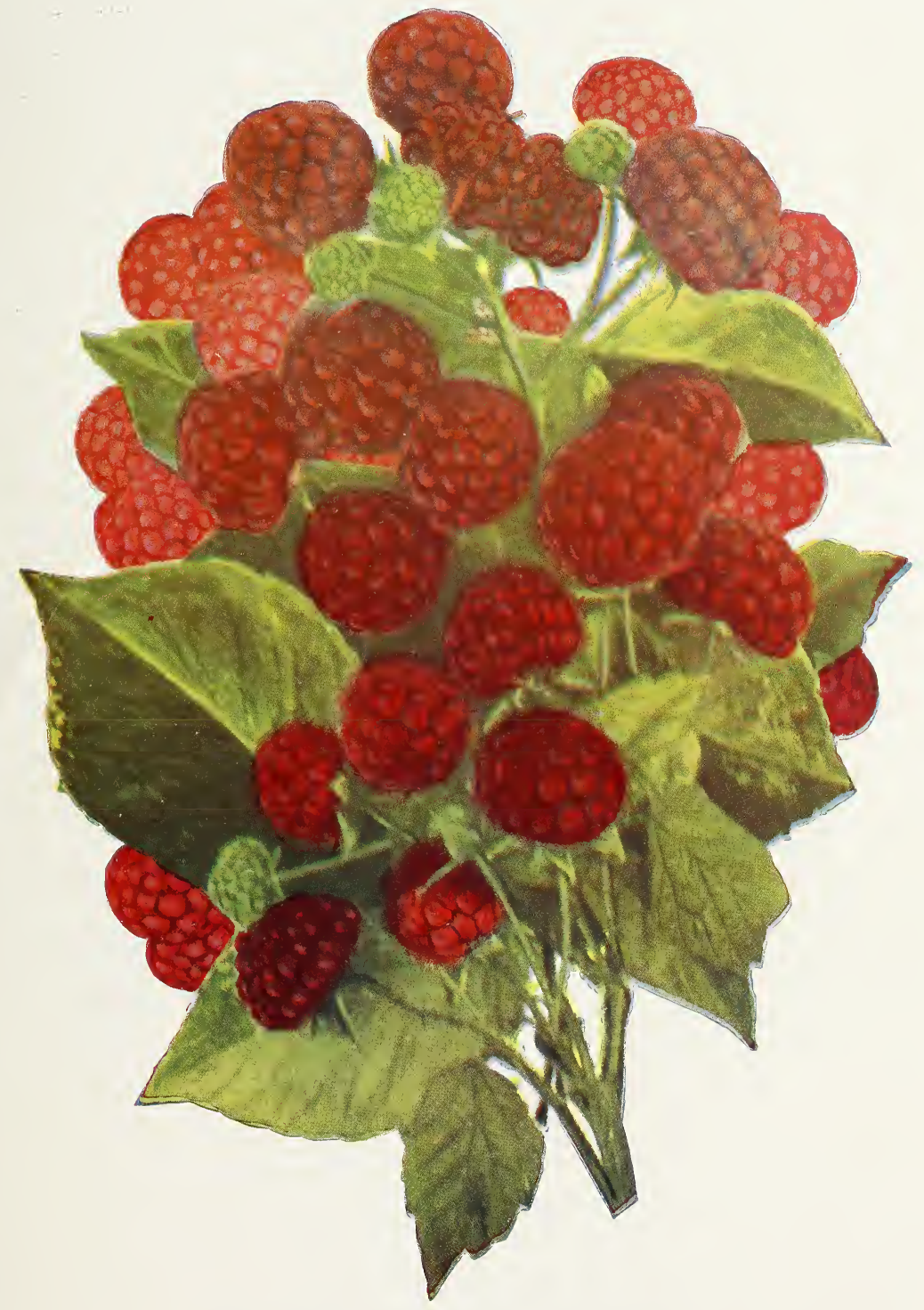

St. Regis Everbearing Raspberries

(For description see page 18 ) 


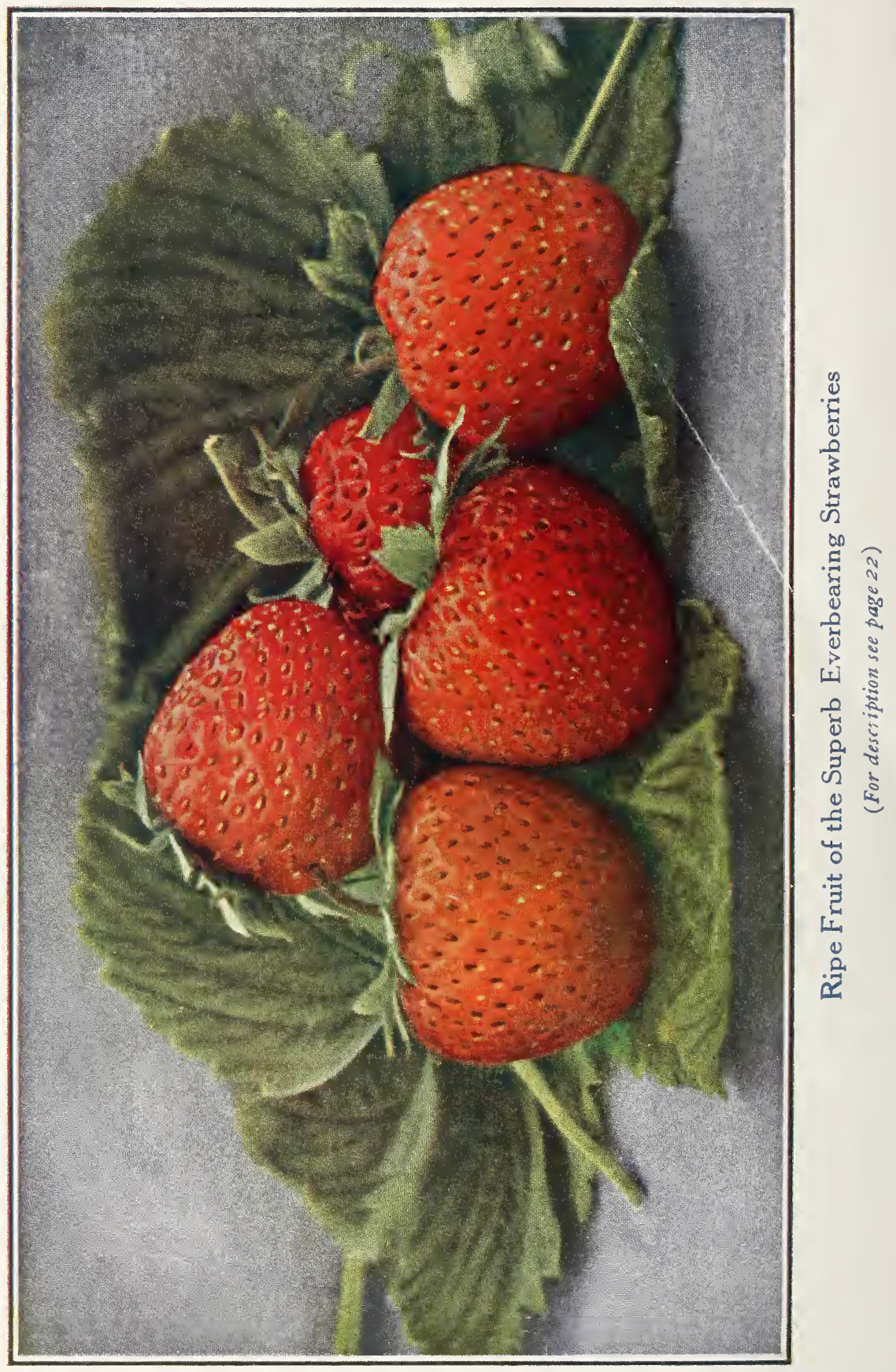

